\title{
Metal bioaccumulation and physiological condition of the Pacific oyster (Crassostrea gigas) reared in two shellfish basins and a marina in Normandy (northwest France)
}

Séguin A. ${ }^{1,2}$, Caplat C. ${ }^{1,2}$, Serpentini A. ${ }^{1,2}$, Lebel J.M. ${ }^{1,2}$, Menet-Nedelec Florence ${ }^{3}$, Costil K. ${ }^{1,2, *}$

${ }^{1}$ Normandie Université, Université de Caen Normandie, F-14032 Caen, France

${ }^{2}$ UMR BOREA (Biologie des Organismes et des Ecosystèmes Aquatiques), MNHN, UPMC, UCBN, CNRS-7208, IRD-207, IBFA, Université de Caen Normandie, Esplanade de la Paix, 14032 Caen Cedex 5, France

${ }^{3}$ LERN (Laboratoire Environnement Ressources de Normandie), IFREMER, Avenue du Gal de Gaulle, BP 32, 14520 Port-en-Bessin, France

* Corresponding author : Katherine Costil, email adress : katherine.costil@unicaen.fr

\begin{abstract}
:
A 5-month experiment combining a geochemical survey of metals with a bioaccumulation study in batches of Crassostrea gigas was conducted in two shellfish farming areas and a marina in Normandy (France). Various endpoints at different levels of biological organization were studied. ROCCH data showed differences in biota contamination between the two shellfish areas but the present study revealed only slight differences in metallic contamination and biomarkers. By contrast, significantly different values were recorded in the marina in comparison with the two other sites. Indeed, higher levels of $\mathrm{Cd}, \mathrm{Cu}$ and $\mathrm{Zn}$ were measured in the oysters from the marina, and these oysters also showed a poorer physiological condition (e.g., condition index, histopathological alterations and neutral lipid content). For coastal monitoring, the multi-biomarker approach coupled with an assessment of metallic contamination in biota appeared to be suitable for discriminating spatial differences in environmental quality after only a few months of exposure.
\end{abstract}

Keywords: Crassostrea gigas, Metallic contamination, Bioaccumulation, Physiological condition, Oxidative stress, France 


\section{Introduction}

Intertidal zones are highly changing environments in terms of abiotic parameters mainly due to tidal influence and are considered one of the most challenging environments on earth. Environmental factors, such as temperature, salinity and suspended organic matter, are relevant physical parameters that drive the adaptation of individuals at each tide (Freire et al., 2012). In addition to these abiotic fluctuations, a wide range of contaminants [e.g., metals, polycyclic aromatic hydrocarbons (PAHs), polychlorinated biphenyls (PCBs), pesticides, and emerging contaminants] are commonly found in littoral ecosystems. There is a growing body of evidence showing that the main source of contaminants in coastal ecosystems originates from anthropogenic effluents carried by rivers from industrial, agricultural and urban areas (Sun et al., 2012). The Normandy (northwest France) coastal sites selected for this work are under the influence of inputs originating from Seine, well known for its high level of contamination (Cachot et al., 2006; IFREMER, 2007).

This combination of anthropogenic contamination and stressing abiotic parameters could impact these intertidal areas where various species of filter-feeder bivalves are reared for shellfish production. In Normandy, oyster stocks sporadically experience summer mortalities of varying intensity, and oysters are undergoing active gametogenesis during the summer season (Costil et al., 2005; Royer et al., 2008). This life-cycle period is particularly constraining because it requires high levels of metabolism and energy resources; this condition may thus destabilise the oyster energy balance (Samain and McCombie, 2007). This imbalance is suspected to weaken oysters and make them more susceptible to mortality in the presence of other risk factors, including contaminants (Samain and McCombie, 2007). Mollusc bivalves, including oysters, are suitable animals for biomonitoring surveys due to their particular life traits, such as a sessile and filter-feeding behaviour, a wide geographical distribution, and a relative resistance to pollutants (Goldberg, 1986). Furthermore, mollusc bivalves have the 
capacity to accumulate many chemical compounds at levels of $10^{3}$ at $10^{5}$ compared with those in environment with a limited ability to metabolize these compounds. These characteristics make oysters suitable species for linking contaminant exposure to their potential biological effects (Goldberg, 1986; Oliver et al., 2001; Valdez Domingos et al., 2007). Finally, these bivalves are often used as sentinel organisms due to their ability to adapt rapidly in a new environment. Individuals from one population (e.g., from a shellfish farm or a control site) can thus be transferred to different testing sites and maintained under caging conditions. This strategy allows tracking the same population throughout the experiment (e.g., for growth and mortality surveys) and consequently reducing biological variability (Viarengo et al., 2007).

In the context of coastal monitoring, an integrated approach including both biomarkers and measurements of metal levels in biota was utilized to obtain a better understanding of the impact of contaminants on coastal organisms (Nasci et al., 1999). The battery of selected biomarkers utilized in the present study included descriptors derived from different levels of biological organization, from the individual scale (survival, growth, and reproduction) to infra-individual descriptors, such as histological, histochemical and biochemical endpoints. Before interpreting biomarker results, it is important to consider the general health status of oysters because these intrinsic factors could constitute confounding factors (Au, 2004; Cuevas et al., 2015). Mortality rates, biometric and histological parameters provide information regarding the apparent "health" of a stock of cultured bivalves (Lucas and Beninger, 1985; Viarengo et al., 2007) Unsaturated neutral lipids (UNLs) contribute to energy resources in Crassostrea gigas, and, environmental contamination generally leads to a depletion of energy reserves (e.g., Nicholson and Lam, 2005; Sokolova, 2013; Valdez Domingos et al., 2007). Biochemical endpoints, such as glutathione-S-transferase (GST) and catalase (CAT) activities and lipidic peroxidation are biomarkers indicating the level of oxidative stress experienced by cells (Manduzio et al., 2005). 
The present study aimed (1) to test the relevance of a battery of selected biomarkers (e.g. individual, histological, histochemical, and biochemical biomarkers) on C. gigas and the feasibility of using these in the framework of coastal area biomonitoring and (2) to characterize the seawater quality of three sites along the Normandy coast a priori with contrasting contamination levels.

\section{Material and methods}

\section{Presentation of sampling sites}

The field study was conducted on the French coast of the English Channel at three sites in Normandy (Fig. 1). Saint-Vaast-la-Hougue (SV) and Baie des Veys (BDV) are both shellfishproducing areas that are differentiated by a pronounced estuarine influence in BDV where salinity can decrease to $22 \mathrm{PSU}$ at ebb tide even during a period of low rainfall (Costil et al., 2005). The two shellfish-producing areas (BDV and SV) show a similar bathymetric level with an immersion time of approximately $80 \%$. With regards to the watershed impact on both shellfish areas, differences can be noticed in terms of size and human activities. With a surface of $3,500 \mathrm{~km}^{2}$, the BDV watershed is 28 -fold greater than that of SV. Freshwater enters the southern part of the bay from four rivers crossing agricultural lands (cattle) and areas with industrial activities, such as food factories. The SV region is principally characterized by intensive vegetable growing and by the city port of SV. Compared with other shellfish areas in France, including in Normandy, the trophic resources at the BDV and SV sites are high but more important at BDV than at $\mathrm{SV}$, as shown by the concentration of chlorophyll- $a$, which averaged $3.00 \pm 0.08 \mu \mathrm{g} . \mathrm{L}^{-1}$ at $\mathrm{BDV}$ and $2.37 \pm 0.18 \mu \mathrm{g} . \mathrm{L}^{-1}$ at $\mathrm{SV}$ (means of monthly measurements from 2005 to 2008) (Grangeré et al., 2012; RHLN, 2015). To provide contrast 
from a contamination point of view with these two sites of economic interest, another study station in Courseulles-sur-Mer (CsM), which provides a marina and fishing port, was selected. The marina of CsM is the outfall for the Seulles River and is characterized by $450 \mathrm{~km}^{2}$ of watershed. However, because of the topography of the river only a small amount of freshwater can penetrate inside the port (RHLN, 2008).

To characterize the chemical contamination level of these study sites, data from the ROCCH (Réseau d'Observation de la Contamination CHimique du milieu marin, ex-RNO) monitoring network conducted by IFREMER were used and compared to national or European norms and regulations. This analysis could only be focused on the two shellfish farming sites (BDV and SV) because no ROCCH monitoring stations exist close to the CsM marina. The chemical concentrations of 41 compounds belonging to eight different chemical classes were measured in biota (November 2013), sediments (June 2013), and seawater (March 2012 - March 2013), in accordance with the Water Framework Directive. Among this data, only the results for inorganic and organic compounds exceeding the norms and regulations and the results for metals of interests monitored in the present study are presented in this manuscript, reducing the number of compounds to 11 chemicals belonging to five classes (metals, PCBs, PAHs, phthalates and phenolic compounds). The norms and regulations are briefly reviewed in appendix A.

The data (mean or maximum) provided by the ROCCH network for each compound measured in seawater, sediment and biota (Tables 1,2 and 3, respectively) were considered by referring to the norms and regulations described in Appendix A. The analysis of this database focused on some organic compounds and metals considered to be particularly toxic for marine life, such as $\mathrm{Hg}, \mathrm{Cd}, \mathrm{Ag}, \mathrm{Ni}, \mathrm{Se}, \mathrm{Pb}, \mathrm{Cu}, \mathrm{Cr}$, As and $\mathrm{Zn}$ (Shahidul Islam and Tanaka, 2004). The site 
showing the highest concentrations and the most exceedances was considered to be more impregnated in contaminants than the other. If considering average values in seawater, a threshold overrun (AA-EQS) for nonylphenol was recorded at BDV (Table 1). If considering maximum recorded values, threshold overruns occurred for three metals (at both sites) and for octylphenol, which was measured at higher concentrations at BDV. The main sources of these pollutants are urban and industrial discharges (e.g. surface treatments and oil miscibility) (AESN-AQUASCOP, 2008). The analyses performed on sediments from SV revealed a higher contamination of $\mathrm{Pb}$ (when considering norms and regulations), whereas the sediments at BDV showed more threshold exceedances $(\mathrm{Cd}, \mathrm{Ni}$ and $\mathrm{Cu})$ and a higher (2.6-fold) concentration of $\mathrm{Cd}$ (Table 2). However, the $\mathrm{Cu}$ level did not exceed the mean geochemical backgrounds given in Normandy (AESN-AQUASCOP, 2008). These metals originate from various sources including the urban runoff, surface treatment and municipal waste incineration (AESNAQUASCOP, 2008). In biota (mussels), four contaminants ( $\mathrm{Hg}, \mathrm{Ni}, \mathrm{Pb}$ and $\mathrm{Ag}$ ) out of eight were found in markedly higher ( $>$ 2-fold) concentrations at SV compared with BDV (Table 3). Moreover, more exceedances in relation to norms and regulations (four out of seven) were noted at SV. Finally, the global assessment of the chemical contamination of both shellfish-producing areas indicated differences in the contamination of both sediments and biota. SV was characterized by higher metallic concentrations in biota, whereas BDV presented $\mathrm{Cd}, \mathrm{Cu}$ and $\mathrm{Ni}$ contamination in sediments. Both sites were affected by organic contamination, as demonstrated by the presence of CB153 in biota and of fluoranthene and CB153 in sediments sampled at both sites. However, by comparison with the contamination in other oyster rearing areas (e.g. Brittany), BDV and SV appear similarly (Cu, Ni, PCB 153 and fluoranthene) or less ( $\mathrm{Pb}, \mathrm{Cd}, \mathrm{Hg}, \mathrm{Zn}$, lindane and DDT) contaminated, except for Ag (IFREMER, 2007).

\section{Biological material}


The oysters studied during the field monitoring were produced by spawners with a wild origin at the SATMAR (Société ATlantique de MARiculture) hatchery in August 2011. They were grown in an oyster farm at Saint-Vaast-la-Hougue (SV) until the study started in February 2013, when the oysters were 18 months of age. For these reasons, SV can be considered a reference (but not pristine) site, and T0 can also be used as a reference for the results. Since 2008, significant mortalities associated with Ostreid herpesvirus (OsHV-1 $\mu$ var) have been observed in French juvenile oyster livestock. To assess the risk of abnormally high mortality rates, the viral loads were thus quantified in April 2012 at the "Centre de Référence sur l'Huître" (CRH) through real time TaqMan ${ }^{\circledR}$ PCR. Ten pools of five oysters were analysed, and only one was slightly infected $\left(11 \times 10^{3}\right.$ genomic units); however, this viral infection could not induce mortality (A. Jouaux, personal communication).

\section{Experimental design}

Oysters were planted at each site in one oyster bag and the three batches were homogeneous in weight. At the two shellfish area sites, the oyster bags (534 individuals per bag) were placed on metal tables, whereas in the marina, the bag was hanging from the dock. Fifteen days after the beginning of the experiment, sub-batches of 50 oysters, which were homogeneous in length $[40.8 \pm 7.7 \mathrm{~mm}($ ANOVA; $\mathrm{p}=0.99)]$ and weight $[6.14 \pm 2.43 \mathrm{~g}($ ANOVA; $\mathrm{p}=0.96)]$, were constituted at each site to monitor the growth of the same oyster batch throughout the experiment. Oysters were sampled and brought back to the laboratory at eight dates, from T0 (February 2013) to T5 months (T5m) (Table 4). Depending of the earliness of the expression of the biomarkers, individual, histological and biochemical endpoints were then studied at different dates. Metal analyses in oysters were performed after 15 days, 3 months and 5 months. 


\section{Metal analyses}

\subsection{Preparation of samples}

Samples were prepared according to the protocol from Caplat et al. (2012). Fifteen oysters per site were transferred to a polyethylene bottle and stored in a freezer $\left(-20^{\circ} \mathrm{C}\right)$. After dissection of their tissues, three pools of five oysters were constituted and stored in a freezer before freezedrying. Dried samples were then digested with $10 \mathrm{~mL}$ of nitric acid $(69 \% \mathrm{VWR}$ - AnalR Normapur $\left.{ }^{\circledR}\right)$ in a microwave digestion system (Berghof ${ }^{\circledR}$ MWS-2) under controlled temperature $\left(205^{\circ} \mathrm{C}\right)$ and oven power $(1000 \mathrm{~W})$ conditions. The digested solutions were transferred to labelled bottles, and ultrapure water was added to obtain a final volume of $50 \mathrm{~mL}$. The bottles were then stored at $4^{\circ} \mathrm{C}$ prior to metal analyses.

One litre of seawater per site was immediately acidified to $0.5 \%$ with nitric acid (69\% VWR AnalR Normapur ${ }^{\circledR}$ ), filtered at $0.45 \mu \mathrm{m}$ within 24 hours, and stored at $4^{\circ} \mathrm{C}$ before analysis of the dissolved fraction.

\subsection{Analysis protocol}

The total concentration of 21 trace elements in seawater samples (Al, As, $\mathrm{Ba}, \mathrm{Ca}, \mathrm{Cd}, \mathrm{Co}, \mathrm{Cr}$, $\mathrm{Cu}, \mathrm{Fe}, \mathrm{Mg}, \mathrm{Mn}, \mathrm{Mo}, \mathrm{Ni}, \mathrm{P}, \mathrm{Pb}, \mathrm{S}, \mathrm{Si}, \mathrm{Sn}, \mathrm{Sr}, \mathrm{Ti}$, and $\mathrm{Zn}$ ) and 23 trace elements in biota (same elements $+\mathrm{Sc}$ and $\mathrm{Se}$ ) were measured through induced coupled plasma-atomic emission spectroscopy (Vista MPX, Agilent Technologies ${ }^{\circledR}$ Santa Clara, USA). To assess the quality of the biota treatment procedure, a standard reference material (SRM NIST-1566b oyster tissue from the National Institute of Standards and Technology, Gaithersburg ${ }^{\circledR}$, MD, USA) was analysed with a sample series. The relative errors between the measured and certified values given for the metal concentrations reached 0.4 to $4 \%$ for $\mathrm{As}, \mathrm{Ca}, \mathrm{Cd}, \mathrm{Cu}, \mathrm{Fe}, \mathrm{Mg}, \mathrm{Mn}, \mathrm{Pb}, \mathrm{Sr}$, and $\mathrm{Zn}, 20$ to $30 \%$ for $\mathrm{Co}$ and $\mathrm{Ni}$, and $50 \%$ for $\mathrm{Al}$. Appropriate blanks were also analysed in series with the samples. In seawater, the detection limits defined as the mean plus three times 
of the standard deviation were less than $10 \mu \mathrm{g} . \mathrm{L}^{-1}$ for $\mathrm{Ba}, \mathrm{Cd}, \mathrm{Co}, \mathrm{Cr}, \mathrm{Cu}, \mathrm{Mn}, \mathrm{Mo}, \mathrm{Ni}, \mathrm{Sc}, \mathrm{Sr}$, and $\mathrm{Ti}$ and less than $35 \mu \mathrm{g} . \mathrm{L}^{-1}$ for $\mathrm{Al}, \mathrm{Pb}, \mathrm{Sn}, \mathrm{Fe}, \mathrm{Mg}, \mathrm{As}, \mathrm{P}, \mathrm{Se}$, and $\mathrm{Zn}$. The detection limits given in solid phase were inferior to $10 \mu \mathrm{g} \cdot \mathrm{g}^{-1}$ for $\mathrm{As}, \mathrm{Ba}, \mathrm{Cd}, \mathrm{Co}, \mathrm{Cr}, \mathrm{Cu}, \mathrm{Mn}, \mathrm{Mo}, \mathrm{Ni}, \mathrm{P}, \mathrm{Pb}$, $\mathrm{Sc}, \mathrm{Se}, \mathrm{Sn}, \mathrm{Sr}, \mathrm{Ti}$, and $\mathrm{Zn}$, inferior to $30 \mu \mathrm{g} . \mathrm{g}^{-1}$ for $\mathrm{Fe}$ and $\mathrm{Mg}$ and inferior to $100 \mu \mathrm{g} \mathrm{g}^{-1}$ for $\mathrm{Al}$, $\mathrm{Ca}$ and Si.

\section{Studied endpoints}

\subsection{Individual and histological biomarkers}

From T15d to T3m, mortality was checked to discard dead oysters and calculate the daily mortality rates according to the following formula: $((N d / N a) \times 100) /(t 2-t 1)$, where $N d$ and $\mathrm{Na}$ correspond to dead and live oysters, respectively, and $t 2-t 1$ corresponds to the time between two consecutive sampling dates. At T15d and T3m, the growth in terms of both weight (to the nearest $0.01 \mathrm{~g}$ ) and length (to the nearest $0.01 \mathrm{~mm}$ ) was measured in the sub-batches devoted to biometry. At T0, T1.5m, T2m and T3m, the oysters sampled for histopathology and measurements of the enzymatic activities endpoints were also used to determine the AFNOR

condition index, which was calculated as follows: $C I$ AFNOR $=\left(\frac{\text { flesh weight }}{\text { total weight }}\right) \times 100$, where the flesh and total weights are expressed in mg. For the histology approach, oyster cross sections ( $\sim 5 \mathrm{~mm}$ in thickness) were cut behind the labial palps and fixed in Davidson's solution. The tissue samples were then routinely processed (Mottier et al., 2015), and 3- $\mu \mathrm{m}$-thick paraffinembedded sections were stained according to the trichrome protocol described by Prenant Gabe (Gabe, 1968). The gender of each oyster was determined once gametogenesis was sufficiently advanced, and the gametogenesis stage was determined according to Lubet's modified classification (Costil et al., 2005). Because of the study period, three main stages were observed in the present study: stages I, II and III. Stage I corresponds to the early developing stage, when the connective tissue of the gonadal area remains very abundant; in gonadal tubules, gonial 
mitoses occur, and only oogonia in females and spermatogonia in males can be observed. During stage II, the connective tissue is in regression, but the gonadal tubules remain well separated from each other; in male oysters, the tubules can contain all germinal cell types, from spermatogonia to spermatozoa, and in female tubules, oogonia and both early and mature oocytes coexist. Stage II lasts several months in oysters reared in northwest France and corresponds to various degrees of gonad development and gametogenesis (Costil et al., 2005). For this reason, this stage was divided into two sub-stages: early stage II (IIe) and welladvanced stage II (IIwa). Stage III corresponds to sexual maturity and is divided in several substages including IIIA and IIIB. In stage IIIA, the oyster's gonad contains both immature and ripe gametes, whereas in IIIB, it contains only ripe gametes, and the animals are ready to spawn or even have begun to spawn. In addition to the gametogenesis stage determination, the reproductive effort of each individual was assessed by calculating the proportion of gonadal tissue in relation to the whole tissue of the visceral mass. To do that, the histological slides were scanned with an Epson Perfection 3200 Photo $^{\circledR}$ Scan digitizing table and then analysed using Imaq Vision Builder software (National Instruments ${ }^{\circledR}$ ) (Royer et al., 2008). The histological slides were also examined to determine tissue alterations which were semi-quantified according to a scale with four levels from slight (score of 1) to severe (score of 4) (Buisson et al., 2008; Mottier et al., 2015).

\subsection{Histochemical biomarker: unsaturated neutral lipids}

The oyster digestive gland was processed for histochemistry, and $8-\mu \mathrm{m}$-thick frozen sections were stained with Oil Red O to reveal unsaturated neutral lipids (UNLs) according to Moore (1988) and Guerlet et al. (2006). For each sample, eight fields of view were randomly photographed on areas belonging to digestive tissues using a video camera (Nikon ${ }^{\circledR}$ digital camera DXM1200C) connected to a photonic microscope (Nikon ${ }^{\circledR}$ Eclipse 80i, X400). UNLs 
were then quantified by image analysis (Imaq Vision Builder, National Instruments ${ }^{\circledR}$ ) by considering the following stereological parameter: surface density $S v \mathrm{UNL}=(4 / t) \times A A$, where $S v \mathrm{UNL}=$ surface density of unsaturated neutral lipids, $\mathrm{t}=$ thickness of cross section $(8$ $\mu \mathrm{m}), A A=$ percentage of the field of view occupied by UNLs in the digestive gland divided by the percentage of the field of view occupied by digestive gland tissue (Guerlet et al., 2006). UNLs were expressed in $\mu \mathrm{m}^{-1}$.

\subsection{Biochemical endpoints}

\section{Sample preparation}

At the day of sampling, oyster flesh was removed from the shell and immediately placed at $80^{\circ} \mathrm{C}$. For protein extraction, the samples were ground in a mortar with liquid nitrogen, and extraction was then performed in phosphate buffered saline (PBS) $(500 \mathrm{mM} \mathrm{NaCl}, 10 \mathrm{mM}$ $\mathrm{Na}_{2} \mathrm{HPO}_{4}$, and $3.1 \mathrm{mM} \mathrm{KH} \mathrm{PO}_{4}, \mathrm{pH}$ 7.4) containing 1\% antiprotease cocktail [Halt Protease Inhibitor Cocktail, EDTA-Free (100X) (Thermo Fisher Scientific ${ }^{\circledR}$, Waltham, MA, USA)] at a ratio of $1 \mathrm{w} / \mathrm{v}$ (weight/volume). The homogenates were then centrifuged twice at 12,500 $\mathrm{g}$ and $4^{\circ} \mathrm{C}$ for $15 \mathrm{~min}$ (S9 fraction), and the supernatants were aliquoted and stored at $-80^{\circ} \mathrm{C}$.

\section{Protein content}

The protein contents were determined using the Bio-Rad Protein Assay kit (Bio-Rad ${ }^{\circledR}$ ) according to Bradford (1976). Ten microliters of the samples or bovine serum albumin (BSA) (standard: 0-500 mg. $\mathrm{L}^{-1}$ ) were then deposed in a well of a microplate, and $200 \mu \mathrm{L}$ of Bio-Rad reagent was then added to the well (diluted $1 / 5$ in ultrapure water). The absorbance at $595 \mathrm{~nm}$ was determined with a microplate reader (Flexstation 3, Molecular Device ${ }^{\circledR}$, Sunnyvale, CA, USA), and the results are expressed as $\mathrm{mg}$ of total protein per $\mathrm{mL}$ (mg proteins. $\mathrm{mL}^{-1}$ ). The 
enzymatic activities and lipid peroxidation results were normalized to the total protein content in the supernatants.

\section{Catalase}

The catalase activities were measured using the protocol described by Babo and Vasseur (1992) with some modifications to allow microplate reading by considering the decrease in absorbance due to hydrogen peroxide consumption. One hundred microliters of the samples were deposed in the wells of a UV microplate (UV star, Greiner Bio-One $\left.\mathrm{Gmbh}^{\circledR}\right)$, and $100 \mu \mathrm{L}$ of $\mathrm{H}_{2} \mathrm{O}_{2}(28$ $\mathrm{mM}$ ) were then added. Kinetic measurements were made at $240 \mathrm{~nm}$ and $25^{\circ} \mathrm{C}$ for $15 \mathrm{~min}$ in a microplate reader (Flexstation 3, Molecular Device ${ }^{\circledR}$ ). The results are expressed as catalase units per mg of proteins (U CAT/mg proteins).

\section{Glutathione-S-transferase}

The GST activities were measured through the method described by Habig et al. (1974), which was adapted for microplate reading by quantifying the increase in absorbance due to 1glutathion-2,4-dinitrobenzene (GS-DNB) formation. Fifty microliters of the samples were then deposited into the wells of a microplate with $200 \mu \mathrm{L}$ of the solution reagent (GSH $1 \mathrm{mM}$, Hepes $10 \mathrm{mM}, \mathrm{NaCl} 125 \mathrm{mM}$, and CDNB $1 \mathrm{mM}, \mathrm{pH}$ 6.5). Kinetic measurements were performed at $340 \mathrm{~nm}$ and $25^{\circ} \mathrm{C}$ for $20 \mathrm{~min}$ in a microplate reader (Flexstation 3, Molecular Device ${ }^{\circledR}$ ). The results are expressed in nmol GS-CDNB. $\mathrm{min}^{-1} \cdot \mathrm{mg}^{-1}$ proteins.

\section{Malondialdehyde content}

The malondialdehyde (MDA) accumulation was used as a lipid peroxidation marker. The MDA contents were measured with an MDA-586 assay kit (Oxis-Research ${ }^{\circledR}$, Portland, OR, USA) according to the manufacturer's instructions. Thirty microliters of the samples or the MDA 
standard were mixed on ice with $1.5 \mu \mathrm{L}$ of probucol, $96 \mu \mathrm{L}$ of diluted $\mathrm{R} 1$ reagent, and then with $22.5 \mu \mathrm{L}$ of $\mathrm{R} 2$ reagent. After $60 \mathrm{~min}$ of incubation at $45^{\circ} \mathrm{C}$ in a dry bath incubator, the samples were centrifuged at $10,000 \mathrm{~g}$ for 10 minutes. Eighty microliters of the supernatants were then deposited in the wells of a microplate. Endpoint measurements were made at $586 \mathrm{~nm}$ with a microplate reader (Flexstation 3, Molecular Device ${ }^{\circledR}$ ). The results are expressed in nmol MDA.mg ${ }^{-1}$ proteins.

\section{Statistical analyses}

The statistical significance of the differences recorded between sampling dates or sites was assessed. Data that did not show homoscedasticity and/or that did not meet the assumption of normality were analysed with Kruskal-Wallis $(\mathrm{K}-\mathrm{W})$ non-parametric tests. Comparisons between sites or dates were then performed with post-hoc Dunn tests. Data that met the conditions above were tested through one-way ANOVAs, and differences among dates or sites were then analysed with post-hoc Student Newman Keuls (SNK) tests. The significance of the differences in daily mortality rates between sites and dates were tested with $\mathrm{Chi}^{2}$ tests, and the proportions of the different gametogenesis stages and genders between sites were analysed using Fisher's exact tests. The statistical analyses were performed using STATISTICA 8.0 software (Statsoft ${ }^{\circledR}$, Tulsa, OK, USA).

\section{Results}

\section{Assessment of the level of metallic contamination}

The results from seawater and biota samples collected during the experiment were interpreted following the same approach that was used for the ROCCH data. Indeed, for each compound, 
the concentrations obtained in seawater and biota were compared between sites and dates, but also by referring to norms and regulations.

At T1.5m, two metals $(\mathrm{Cd}$ and $\mathrm{Cu})$ were detected in seawater at concentrations of $1.2 \mu \mathrm{g} . \mathrm{L}^{-1} \mathrm{Cd}$ and $11.8 \mu \mathrm{g} . \mathrm{L}^{-1} \mathrm{Cu}$ in BDV and CsM, respectively (data not shown). However, at T3m, the metal concentrations were below the detection limit for all sites.

As soon as the first sampling date (T15d), the metal concentrations were higher in the oysters from $\mathrm{CsM}(\mathrm{Cd}$ and $\mathrm{Pb})$ and $\mathrm{BDV}(\mathrm{Pb})$ compared with the concentrations detected in the oysters from SV (Fig. 2). At T3m, three out of the five contaminants ( $\mathrm{Cd}, \mathrm{Cu}$ and $\mathrm{Zn}$ ) were found at higher concentrations in the oysters placed in the marina of CsM. At T5m, the concentrations of $\mathrm{Cd}, \mathrm{Cu}$ and $\mathrm{Zn}$ remained higher in animals from $\mathrm{CsM}$ compared with those from the two other sites. With regards to the two shellfish basins, the results revealed no clear differences, with the exception of $\mathrm{Pb}$ and $\mathrm{As}$ at $\mathrm{SV}$, where the oysters were more contaminated at $\mathrm{T} 5 \mathrm{~m}$.

Considering the norms and regulations, differences appeared as soon as T15d for lead at BDV and CsM. At T3m, two out of four (no norms and regulations for arsenic) metals overpassed more norms and regulations at $\mathrm{CsM}(\mathrm{Cd}$ and $\mathrm{Cu})$. At T5m, two overpassing metals $(\mathrm{Cu}$ and $\mathrm{Pb})$ were again recorded, and the concentrations in $\mathrm{Pb}$ were particularly high at the three study sites.

\section{Individual and histological biomarkers}

\subsection{Mortality}

The daily mortality rates after 15 days reached $0.32 \%$ and $0.43 \%$ in the oyster batches transplanted to BDV and CsM, respectively, whereas the corresponding rate was $0.24 \%$ for the oysters that remained at SV. At the other sampling dates, the daily mortality rates were generally slightly higher at CsM but remained low ( 0.02 - 0.1\%) regardless of the site. The cumulative mortality rates recorded during the study were $7.98 \%$ and $9.91 \%$ at $\mathrm{SV}$ and BDV, 
respectively, and reached $13.73 \%$ at CsM. However, no significant differences were found between sites $\left(\mathrm{Chi}^{2}\right.$ tests; $\left.\mathrm{p}>0.05\right)$.

\subsection{Growth and condition index}

After the three-month experiment, the length and weight of the oysters placed at BDV $(50.24 \pm$ $9.18 \mathrm{~mm}$ and $6.14 \pm 2.45 \mathrm{~g}$, respectively) were significantly higher compared with those of the oysters at the two other sites (ANOVAs: $p<0.001$ and SNK tests: $p<0.05$ ) (Fig. 3). The condition index (CI) for the oysters placed at the three sites increased during the study (ANOVAs, $\mathrm{p}<0.001$ ); indeed, the CI values at T3m reached 15.16 $\pm 2.73,17.85 \pm 2.83$ and $19.43 \pm 3.51$ at $\mathrm{CsM}, \mathrm{BDV}$ and $\mathrm{SV}$, respectively, whereas it was only $9.32 \pm 2.52$ at the beginning of the experiment (SV T0) (Fig. 4). At T1.5m and T2m, no significant differences were recorded between the oysters from the three sites (ANOVAs; $p>0.05$ ); in contrast, at $\mathrm{T} 3 \mathrm{~m}$, the oysters from the marina (CsM) showed a significant lower CI compared with the oysters from the two shellfish basins (ANOVA: $p<0.001$; SNK tests: $p<0.01$ ).

\subsection{Gametogenesis stages and assessment of the reproductive effort}

The oyster gender was determined only when the gametogenesis cycle was sufficiently advanced (stage IIwa; T3m and T5m) to avoid potential errors. Five (14\%) and seven (18\%) simultaneous hermaphrodites were observed at $\mathrm{CsM}$ and $\mathrm{SV}$, respectively, whereas no hermaphrodites were found at BDV. By considering only males and females, it appeared that the sex ratio was well-balanced in the marina of CsM (Fisher's exact test: $p=0.29$ ) and unbalanced in favour of males $(\sim 85-90 \%)$ in the two shellfish-producing areas (Fisher's exact tests: $\mathrm{p}<0.001)$.

At the beginning of the study (February), the oysters were at stage I (gonial mitosis) (Fig. 5). The course of gametogenesis began to differ between sites only from T3m, when some individuals from CsM were still at stage I, whereas in the two other sites, all of the oysters were 
at stage II (IIe or IIwa) (Fisher's tests: $\mathrm{p}<0.05$ ). Nevertheless, after 5 months, most of the oysters attained sexual maturity (III), but a significantly higher proportion of oysters were ready to spawn or began spawning (IIIB) in the marina of CsM compared with the corresponding proportion of bivalves at the two other sites (Fisher's tests: $\mathrm{p}<0.05$ ). However, at this period of sexual maturity, females appeared proportionally more advanced during the course of gametogenesis compared with males (Fig. 5). Indeed, at BDV and CsM, most of the oysters at stage IIIB were female. When considering the proportion of gonadal tissue after the 5 monthexperiment, the oysters that remained at SV presented the lowest percentage $(26.03 \pm 2.70 \%)$, and the individuals placed at CsM exhibited the highest percentage $(38.67 \pm 3.19 \%)$. The studied oysters at SV significantly differed from those placed at CsM $(\mathrm{p}<0.02)$ and tended to differ from those placed at BDV $(34.72 \pm 1.63 \% ; \mathrm{p}=0.06)$, whereas no significant differences were found between the individuals at CsM and BDV ( $p=0.39$; ANOVA, SNK tests).

\subsection{Histopathology}

The histological slides were examined to determine tissue alterations, such as atrophies of the wall of the digestive tubules (with lumen enlargement), destructurations of the connective tissue (corresponding to poorly developed reserve tissue), and hemocytic infiltrations in connective tissue. Because an atrophy of the wall of the digestive tubules could reflect a transient fasting due to an oyster's transfer to unfavourable conditions, a histological analysis of individuals collected 24 and $48 \mathrm{~h}$ after their transfer to BDV and CsM was performed. The atrophies of the digestive tubules were very moderate, with mean levels always lower than 1 (on a four-point scale), regardless of the site and sampling date. In addition, no significant differences were found between sites at T24h, T48h and T2m, irrespective of the tissue disturbance. Figure 6 thus illustrates only the tissue alterations and the sampling dates, showing significant differences between sites at $\mathrm{T} 1.5 \mathrm{~m}, \mathrm{~T} 3 \mathrm{~m}$, and $\mathrm{T} 5 \mathrm{~m}$ : destructurations of the connective tissue (Fig. 6a) and hemocytic infiltrations (Fig. 6b). At the beginning of the study, the oysters from 
SV showed reserve tissue that was moderately developed (mean index of $2.3 \pm 0.21$ ), and these reserve tissue recovered over time, particularly at SV and BDV. Indeed, the destructurations of the oyster's reserve tissue were significantly more pronounced in the oysters from CsM at T1.5m and T5m (K-W and Dunn tests, $\mathrm{p}<0.05$ ). Hemocytic infiltrations were severe (mean index of $3.37 \pm 0.19$ ) in the oysters from SV at T0, and then these infiltrations extensively decreased. The hemocytic infiltrations were significantly higher in the oysters sampled in the marina of CsM at T3m (compared with BDV) and T5m (compared with SV and BDV) (K-W and Dunn tests, $\mathrm{p}<0.05)$.

\section{Histochemical biomarker: unsaturated neutral lipid content}

Over the three months of the study (February-July 2013), the unsaturated neutral lipid contents (UNLs) increased in the digestive gland of oysters from all of the sites (ANOVAs: $p<0.001$ for the three sites); indeed, the UNL content at $\mathrm{T} 3 \mathrm{~m}$ reached from $0.17 \pm 0.05 \mu \mathrm{m}^{-1}$ and $0.32 \pm$ $0.02 \mu \mathrm{m}^{-1}$ at $\mathrm{CsM}$ and BDV, respectively, compared with $0.05 \pm 0.01 \mu \mathrm{m}^{-1}$ for the bivalves sampled from SV at T0 (Fig. 7). At T1.5m, significant differences were detected between the sites (ANOVA: $\mathrm{p}<0.001$ and SNK tests: $\mathrm{p}<0.001$ ), with a higher value observed at BDV $\left(0.23 \pm 0.03 \mu \mathrm{m}^{-1}\right)$ compared with the values observed at SV $\left(0.17 \pm 0.02 \mu \mathrm{m}^{-1}\right)$ and $\mathrm{CsM}(0.12$ $\left.\pm 0.03 \mu \mathrm{m}^{-1}\right)$. At T2m and T3m, oysters transplanted to CsM showed a significantly lower UNL content compared with the animals from the two shellfish-producing areas (ANOVAs: $\mathrm{p}<$ 0.001 and SNK tests: $\mathrm{p}<0.05)$.

\section{Biochemical biomarkers: oxidative stress regulation}

The GST activities differed significantly between dates at SV and CsM (ANOVAs, $\mathrm{p}<0.01$ and $\mathrm{p}<0.05$, respectively) but not at BDV (ANOVA, $\mathrm{p}=0.74$ ). The examination of GST activities at a given date revealed no significant differences between the three sites from $\mathrm{T} 0$ to 
T48h (results not shown) and T2m (Fig. 8a). At T1.5m, there were significant differences between GST activities in oysters from the three sites. Indeed, these activities were significantly higher in animals placed in the marina of CsM and significantly lower in the oysters sampled at $\mathrm{SV}$ (ANOVA, $\mathrm{p}<0.001$; $\mathrm{SNK}$ tests, $\mathrm{p}<0.05$ ). At T3m, a significant reduction was measured in the bivalves sampled at BDV $\left(8.27 \mathrm{nmol} . \mathrm{min}^{-1} \cdot \mathrm{mg}^{-1}\right.$ of proteins $)$ compared with the two other sites (10.16 and $10.91 \mathrm{nmol} . \mathrm{min}^{-1} . \mathrm{mg}^{-1}$ of proteins at SV and CsM, respectively; ANOVA, $\mathrm{p}<$ 0.01 ; SNK tests, $\mathrm{p}<0.05)$.

At each site, significant differences in catalase activities were detected between dates, and a significant increase was obtained at the beginning of the study for oysters from SV and CsM,

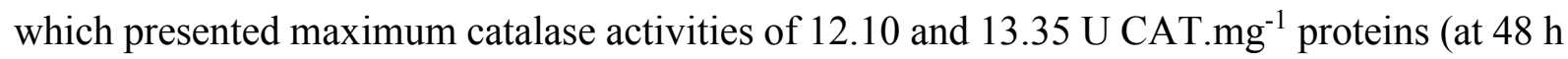
and $24 \mathrm{~h}$, respectively; results not shown). However, despite this peak at T48h observed in the oysters from $\mathrm{SV}$, no significant differences were recorded from $\mathrm{T} 1.5 \mathrm{~m}$ to $\mathrm{T} 3 \mathrm{~m}$. In contrast, at CsM, the values remained high at $\mathrm{T} 24 \mathrm{~h}, \mathrm{~T} 48 \mathrm{~h}$ and $\mathrm{T} 1.5 \mathrm{~m}\left(\approx 13.30\right.$ versus $9.18 \mathrm{U}_{\mathrm{CAT} . \mathrm{mg}^{-1}}$ proteins for SV at T0) (Fig. 8b). Consideration of the individual dates revealed significantly higher CAT activities in oysters from CsM compared with those detected in the animals from the two shellfish-producing areas at T1.5m $(\sim 1.5$-fold higher; ANOVA, $\mathrm{p}<0.001$; SNK tests, $\mathrm{p}<0.001$ ). At $\mathrm{T} 2 \mathrm{~m}$ and $\mathrm{T} 3 \mathrm{~m}$, no differences were found between oysters sampled at the three sites.

As regards MDA content, no significant changes were observed from $\mathrm{T} 0$ to $\mathrm{T} 48 \mathrm{~h}$, regardless of the site (results not shown). During the study, significant increases were recorded for oysters that remained at SV and were sampled at $\mathrm{T} 1.5$ and $\mathrm{T} 2 \mathrm{~m}$ and for oysters placed in BDV and sampled at T2m (ANOVAs, $\mathrm{p}<0.01$ and $\mathrm{p}<0.001$, respectively), whereas the MDA content did not differ in the oysters sampled from CsM (ANOVA, $\mathrm{p}=0.22$; Fig. 8c). Regardless of the date, no significant differences were observed in the MDA content between oysters placed at the three study sites. 


\section{Discussion}

In this section, data regarding contamination and bioaccumulation and then biomarker results are discussed. In both cases, comparisons were made between the shellfish-producing areas (SV and BDV), and additional comparisons were then performed between these sites and the marina of CsM.

\section{Assessment of chemical contamination regarding the field study in the three sites}

The data recorded during this field study showed that BDV and CsM were impacted by the metallic enrichment of ambient seawater, respectively, with $\mathrm{Cd}$ and $\mathrm{Cu}$ at $\mathrm{T} 1.5 \mathrm{~m}$. The levels measured in seawater at SV and at the other dates were under the detection limits. As many trace metals, $\mathrm{Cd}$ is known to present a non-conservative behaviour during the mixing of freshwater and seawater in estuaries (Chiffoleau et al.,1994). Thus, at T1.5m (during a strong flow period that induces high inputs of freshwater into the estuary), the recorded high concentration of dissolved $\mathrm{Cd}$ could be associated to desorption from seaward fluxing riverine particles as well as from resuspended estuarine sediments. At the same date at $\mathrm{CsM}, \mathrm{Cu}$ was found at a higher concentration than those measured at the two shellfish-producing areas and was similar to those recorded in a harbour at Southern Taiwan (Lin et al., 2013). These data show a globally low impregnation of the studied sites by metals. Nevertheless, the pollutant concentrations in waters are susceptible to marked fluctuations due to their variable geochemical behaviours. In further studies, it would be more relevant to take into account sediments that integrate contamination over a longer period and for which more data are available in the literature (e.g. Bebianno et al., 2015). 
Comparisons have been made between data collected in the present study and results reported for species of the genus Crassostrea in areas differentially impacted by metallic contamination. The metal contents in $C$. gigas placed at both sites at shellfish-producing area could be interpreted to be globally similar to those recorded in sites with relatively low contamination (Ochoa et al., 2013; Baudrimont et al., 2005; Vázquez et al., 1993). However, the EAC/EC thresholds for $\mathrm{Cd}$ (at $\mathrm{T} 15 \mathrm{~d}$ and $\mathrm{T} 5 \mathrm{~m}$ ) and $\mathrm{Pb}$ (at T5m) were exceeded, showing a possible risk on marine species (Fig. 2). These results were not confirmed by the ROCCH data from November 2013 in mussels (Table 3). This could be explained by the differences in metabolizing metals between mussels and oysters ( $\mathrm{O}^{\prime}$ Connor and Lauenstein, 2005); in fact, in contaminated environments, oysters accumulate approximately three times as much of this metal as mussels (Boutier et al., 1989). Regardless of the site, the As concentration in oysters remained at high levels compared with those detected in other studies (e.g., Baudrimont et al., 2005; Ochoa et al., 2013), suggesting a regional impregnation by this metal. However, in biota, $90 \%$ of the As is in the form of low toxic organic compounds (arsenobetaine) (AESNAQUASCOP, 2008). Differences in contamination between CsM and shellfish-producing areas were recorded at each date depending on the pollutants. Between T15d (February 2013) and T5m (July 2013), the concentrations of $\mathrm{Cd}$ and As decreased at all sites, whereas the concentrations of $\mathrm{Pb}, \mathrm{Cu}$ and $\mathrm{Zn}$ tended to stagnate ( $\mathrm{SV}$ and $\mathrm{BDV}$, with the exception of $\mathrm{Pb}$ ) or increase (CsM). As shown in various studies, metals do not necessarily show the same pattern of accumulation (vs. mobilization) in tissues and organs (Chan et al., 1999; Marigómez et al., 2002). For example, opposite patterns for the oysters' body burden in terms of $\mathrm{Pb}$ and $\mathrm{Cd}$ with a decrease and an increase in metal concentrations, respectively, were observed in relation to laying (Chan et al., 1999). In the present study, the increase in Pb may likely be explained by gonad development and acquisition of sexual maturation. In contrast, decreases in $\mathrm{Cd}$ (and As) 
could be related to an increase in the metabolic activity or simply to a dilution effect due to an increase in body weight (Chan et al., 1999).

$\mathrm{Cu}, \mathrm{Zn}$ and to lesser extent $\mathrm{Pb}$ were found in greater contents in the flesh of oysters transplanted to CsM, and this appears to be typical of harbour environment contamination, as previously showed by the study conducted by Bazzi (2014). Indeed, $\mathrm{Cu}$ and $\mathrm{Zn}$ are currently used in antifouling paints (Almeida et al., 2007; Turner, 2010), whereas $\mathrm{Zn}$ is also used as a sacrificial anode for the protection of boat hull (Bird et al., 1996). $\mathrm{Pb}$ and $\mathrm{Zn}$ can also originate from runoff from urban areas (gutters, roofs) (AESN-AQUASCOP, 2008), and it is noticeable that the marina of CsM is situated in the city centre. In comparison with the two other sites, oysters in CsM could be considered more contaminated (because biota constitutes a "storage of contamination"). Hence, the $\mathrm{Cd}$ and $\mathrm{Cu}$ content in $C$. gigas transplanted to the marina of $\mathrm{CsM}$ exceeded the EAC/EC thresholds, suggesting toxic effects on these organisms. Nevertheless, the metal contents of $\mathrm{Cd}, \mathrm{Pb}, \mathrm{Cu}$ and $\mathrm{Zn}$ in oysters at $\mathrm{CsM}$ remain relatively low on a global scale compared with the levels found in different bays influenced by important heavy metal pollution, such as NW Sea of Japan in Russia (Shulkin et al., 2003) and Pensacola Bay in Florida (Oliver et al., 2001).

These results therefore confirm differences in metal behaviour in relation to physicochemical variations in water, particularly in cases in which differing partitions occur between dissolved and solid phases $(\mathrm{Cu}$ and $\mathrm{Cd})$. The potential availability of metals $(\mathrm{Cu}, \mathrm{Pb}$, and $\mathrm{Zn})$ for biota is then strongly linked to this mobility, which confirms the pertinence of an ecotoxicology study when high dissolved concentrations are recorded. In situ biota monitoring by caging appears to be a good tool to survey the water quality, particularly in contaminated areas (such as harbour), but the selection of the sentinel species is important because the bioaccumulation of metals may be dependent on the organism. 


\section{Oyster mortality in the three studied sites}

At the beginning of the study (T15d), the daily mortality rates were relatively high at BDV $(0.32 \%)$ and CsM (0.43\%), which could be explained by the stress induced by the transplantation of oysters from SV to BDV and CsM. However, high daily mortality rates were also recorded at the reference site (SV, $0.24 \%$ ), and other mortality causes should be considered. At $\mathrm{T} 15 \mathrm{~d}$, high concentrations of metals $(\mathrm{Cd}, \mathrm{As}$ and $\mathrm{Zn})$ were recorded in the flesh of oysters from all sites. This observation could be explained by watershed leaching and an increase of contamination in surface waters during the winter period. The effect of environmental contamination as well as handling on the constitution of oyster batches could explain the excessive mortality recorded at the beginning of the study. Finally, even though non-significant differences were detected between sites at all dates, the highest cumulative mortality rate $(\sim 14 \%$ for 3 months) calculated for oysters transplanted to CsM could be explained by the higher metal contamination recorded for this site at each date. Nevertheless, this mortality can be considered low in comparison to that found in M. galloprovincialis transplanted into tyre reefs along the bay of Vallauris Golfe-Juan (NW Mediterranean) ( 20-30\% for 6 weeks) (Risso-de Faverney et al., 2010) and in oysters $C$. gigas transplanted into two shellfish basins in Spain ( $20-80 \%$ for 2 months) (Ochoa et al., 2012). The low mortality rates recorded in the present study suggest the high acclimatisation abilities of $C$. gigas individuals placed in contaminated areas.

\section{Comparison of physiological biomarkers between oysters from the two shellfish areas}

No significant differences in the condition index, gametogenesis and histopathology were recorded between the two shellfish-farming sites (SV versus BDV). In contrast, a lower content of unsaturated neutral lipids (UNLs) $(\mathrm{T} 1.5 \mathrm{~m})$, a slower growth in terms of size and weight 
(T3m) and a lower reproductive input (T5m) were observed at SV. These differences could be explained by the lower trophic richness that occurs at this site (Grangeré et al., 2012; RHLN, 2015), which may be coupled with higher metal contamination, as shown by higher values of $\mathrm{Hg}, \mathrm{Ni}, \mathrm{Pb}$ and $\mathrm{Ag}$ detected in mussels at $\mathrm{SV}$ from the ROCCH network (unpublished data). According to Nicholson and Lam (2005) and Sokolova et al. (2012), contamination could deplete energy reserves that were initially intended to growth. Under stressful circumstances, energy reserves are allocated to defence mechanisms, and consequently, animals living in polluted waters often show retarded growth and poor tissue condition. It is important to specify that oysters placed at SV showed greater shell erosion due to strong hydrodynamics, which could also explain the biometric differences between the two sites.

Glutathione S-transferases (GSTs) are crucial enzymes of the cellular detoxification system (phase II enzymes). These enzymes are involved in the catalysis of glutathione with xenobiotics or compounds previously modified by phase I enzymes (to make them more hydrosoluble and then easily removed by organisms). The analyses showed that GST activities were enhanced at BDV and SV at T1.5 and T3m, respectively. At T1.5m, relatively high levels of dissolved Cd were recorded in seawater sampled from BDV. Metals are not natural substrata for GSTs (Vidal-Liñán et al., 2014), but various studies have shown an increase in GST activities in bivalves experimentally exposed to metals, namely $\mathrm{Cu}$ and $\mathrm{Hg}$ (Canesi et al., 1999; Sabatini et al., 2011), or in environments contaminated by metals (Vidal-Liñán et al., 2014). However, after the three-month experiment at SV, no metals were detected in seawater, and no differences in metallic contamination were recorded in the flesh of oysters from both shellfish-producing sites. The inter-site differences in GST activities could not be related to metallic contamination and should originate from other types of contaminants, such as organic compounds (Iummato et al., 2013; Gonzalez-Rey et al., 2014). It is noticeable that the GST increases at both sites 
were low compared with those recorded at CsM. Therefore, no clear differences were observed between the two shellfish-farming areas, where oysters appeared to be in good health.

\section{Physiological biomarkers in oysters transplanted to the CsM marina compared with those from the two shellfish-producing areas}

With regards to size, weight and length, oysters from CsM showed no significant differences compared with the bivalves that remained at SV, but the oysters from both of these sites were lighter and smaller than those from BDV. It is important to note that the oysters transplanted to the marina were continually immersed and therefore had more access to the trophic resource in comparison with the oysters in the two shellfish-producing sites. Despite this benefit, the oysters sampled from CsM did not show a faster growth. Similar observations were made for the condition index (lower values of CI for the oysters from CsM at T3m) and UNLs (lower proportions for oysters placed at CsM and sampled at the three dates). The lower CIs at CsM could be due to the environmental metallic contamination that occurred at this site. Indeed, a similar result has already been recorded in the American oyster $C$. virginica exposed to metallic contamination (e.g. mean Cd concentration of 24 mg.kg-1 dry weight) (Riedel et al., 1998) and in the freshwater mussel Elliptio complanata impacted by treatment plant discharges (Farcy et al., 2011). Unsaturated neutral lipids constitute part of the energy resources in bivalves, and these reserves can be depleted in contaminated environments, as was previously shown by Guerlet et al. (2007) in Dreissena polymorpha and by Zorita et al. (2006) in Mytilus edulis. These lower contents of UNLs and lower CIs may be due to a relocation of energy reserves toward survival mechanisms. Growth delay, poor tissue condition and weaker energy reserves were observed in organisms inhabiting contaminated environments (Guerlet et al., 2007; Nicholson and Lam, 2005; Sokolova et al., 2012). 
In marine bivalves, condition indices are related to the reproductive cycle because spawning induces a decrease in flesh weight and consequently a decrease in the CI (Costil et al., 2005). However, at T3m (May 2013), when significant inter-site differences in the CI were recorded, oysters from all of the sites were at a maximum gametogenesis stage of IIwa (II "well advanced") corresponding to gonadal development. Therefore, the lower condition index of oysters placed at CsM could not be explained by spawning. The course of gametogenesis was in agreement with previous observations made in Baie des Veys (Costil et al., 2005) from February to July. However, in May (T3m), a significant proportion of the oysters reared at CsM remained at stage I, reflecting a delay in gametogenesis at this site. Various studies have shown that a wide range of chemical contaminants could interfere with the reproductive cycle of bivalves: organotin compounds (Siah et al., 2003), DDT insecticide (Binelli et al., 2004), metals and PAHs (Gauthier-Clerc et al., 2002). The results observed at CsM could be related to metallic contamination that occurred at this site but also to other contaminants, such as organic compounds or organotin compounds, which are found in other harbours of Normandy (Michel and Averty, 1999; unpublished data). Gametogenesis delay at T3m could also be linked with lower size and weight as well as the condition index and proportion of UNLs observed in oysters placed at CsM. These results suggest that the exposure of oysters to chemical contaminants induces a disruption in bioenergetics processes resulting in a loss of reproductive output, as was previously reported by McDowell et al. (1999) in M. edulis and Mya arenaria. However, at $\mathrm{T} 5 \mathrm{~m}$, gametogenesis was globally more advanced at CsM (higher proportion of IIIB stages). It is noticeable that female oysters were more represented in samples from CsM and that these female individuals were proportionally more advanced in the reproductive cycle than males. However, in a further study, it would be relevant to consider a higher individual number of both genders to draw definitive conclusions regarding a potential asynchronous cycle at a relatively contaminated site, such as CsM. Moreover, this date (T5m) corresponded to a decrease in Cd 
and $\mathrm{As}$ in the oysters' body burden, whereas the contents of $\mathrm{Pb}, \mathrm{Cu}$ and $\mathrm{Zn}$ were still increasing. In female mussels (Mytilus edulis) at a site close to a $\mathrm{Cu}$ mine, Zorita et al. (2006) observed advanced gametogenesis and hypothesized the $\mathrm{Cu}$ exerts possible toxic effects on mussels and impacts on the hormonal regulation of gamete development. A higher reproductive effort was recorded in bivalves transplanted to $\mathrm{CsM}$ and to $\mathrm{BDV}$ (T5m), and this effect could be due to trophic richness because many authors (e.g., Enríquez-Díaz et al., 2009) have reported that the reproductive effort mainly depends on food rations. However, despite a longer access of oysters to food due to their constant immersion at CsM, the relative high oyster reproductive output was quite surprising when considering other biomarkers (such as growth, CIs and UNLs), indicating a poor physiological condition. These results suggest that the energy of oysters placed at CsM was likely more allocated to the reproductive effort than to growth and reserve constitution. Furthermore, it has been shown that a high reproductive effort is positively correlated with the oyster summer mortality that sporadically occurred in France (Samain and McCombie, 2007), and this could constitute an additional physiological stress factor for oysters placed at CsM (even if low mortality rates were recorded during the 5-month experiment). Atrophy of the digestive tubule walls and destructuration of the connective tissue can be mainly related to the oyster physiological status, whereas hemocytic infiltrations are generally more in line with histopathology. In the present study, low levels and no significant inter-site differences were recorded for atrophy of the digestive tubules, suggesting that the oysters were not fasted during the study. The mean levels of hemocytic infiltrations and destructuration of the connective tissue were rather high at the beginning of the study (T0). However, these levels decreased during the course of field exposure, and at all of the sites, oyster tissue alterations were observed at relatively low levels. Nevertheless, differences in both alterations were recorded between oysters from CsM and the two shellfish-producing basins. During the study, no pathogens were detected through an analysis of histological slides. Without a link to a 
pathogen infection, the hemocytic infiltrations could thus be related to chemical contamination, as was previously reported in marine bivalves exposed to a mixture of diesel oil and copper (Auffret, 1988) and to organic contamination (Nasci et al., 1999). Connective tissue is composed of glycogen storage cells, and destructurations of connective tissue reveal a reduction in storage tissue, illustrating an altered physiological state. At the beginning of the study (February), destructurations were moderate and could reflect the low amount of food during the winter period (Grangeré et al., 2012; RHLN, 2015). At CsM, higher levels of tissue destructurations were noticed at all dates, but the inter-site differences were only significant at $\mathrm{T} 1.5 \mathrm{~m}(\mathrm{SV})$ and at T5m (both sites). As detailed in the literature, freshwater mussels exposed to algae contaminated by $\mathrm{Cu}$ showed serious and numerous destructurations of connective tissue (Sabatini et al., 2011).

At T1.5m, antioxidant defences, represented in the present study by CAT and GST activities, were boosted in oysters placed in the marina of CsM compared with the activities detected in bivalves at $\mathrm{BDV}$ and $\mathrm{SV}$. At this date, $\mathrm{Cu}$ was detected and found in higher concentrations in the marina seawater. As previously observed in various studies (e.g., Attig et al., 2010; Sabatini et al., 2011; Bebianno et al., 2015), metal contamination could increase oxidative stress in bivalves. Nevertheless, the content of MDA, which reveals the level of lipid peroxidation, did not increase at CsM, and oysters appeared to be efficiently protected against oxidative stress. Funes et al. (2006) reported that the oyster Crassostrea angulata exposed to $\mathrm{Cu}$ at a concentration of the same order of magnitude as those recorded at CsM showed increased antioxidant defences and ultimately less extensive oxidative damages than oysters from the less-contaminated site. These researchers (2006) suggested that organisms chronically exposed to polluted environments could acquire compensatory adaptive mechanisms against oxidative stress. However, despite the relative absence of oxidative damage in oysters placed at CsM, the 
relocation of energy for survival mechanisms appeared to be costly for organisms because these bivalves showed a poor somatic condition.

\section{Conclusion}

In the frame of the European legislation about coastal water quality, the present study allowed the valorisation of data from the French mussel watch program (ROCCH network), which is routinely achieved for the last 40 years. In biota, the ROCCH database acquired in 2013 revealed a higher metallic contamination $(\mathrm{Hg}, \mathrm{Ni}, \mathrm{Pb}$, and $\mathrm{Ag}$ ) in mussels (Mytilus sp.) from SV compared with those from BDV, but no exceedances of norms and regulations regarding EAC/EC were observed at both sites. In contrast, the present study showed fewer differences between the oysters from the two sites at shellfish-producing areas but more EAC/EC threshold exceedances $(\mathrm{Cd}$ and $\mathrm{Pb})$, suggesting the high ability of $C$. gigas to bioaccumulate some metals and a potential impact on marine fauna.

Despite a relatively short (maximum of 5 months depending of endpoints) field study, the use of the battery of selected biomarkers revealed its feasibility for littoral biomonitoring. In this battery, the individual and histological biomarkers (e.g. condition index and tissue alterations) and the LNI content assessment revealed especially relevant compared to biochemical biomarkers performed on whole individuals which provided less significant responses.

No lethal but sub-lethal effects were recorded in the three studied sites, and significant intersite differences were observed for some endpoints. Compared with the oysters at SV, the better physiological condition (i.e., growth, lipid reserves and reproductive output) of the oysters transplanted to BDV was likely due to a higher trophic richness, whereas differences between the oysters placed in the two shellfish-producing areas and in the marina of CsM could be linked to environmental constraints, including metallic contamination. Indeed, the individuals 
transplanted to the marina (where they were continuously immerged) showed harmful effects regarding somatic conditions (i.e., weight, condition index, lipid reserves and tissue alterations) but no lethal effects or oxidative stress damages. These results suggest that $C$. gigas shows a high capacity to live in constraining environments, such as contaminated waters. Nevertheless, it would be interesting to assay the survival and fitness of oysters over a long period.

\section{Acknowledgments}

We gratefully acknowledge the staff of the UMR BOREA laboratory in the University of Caen and particularly Christophe Roger and Béatrice Adeline. We thank the SATMAR team, who kindly provided juvenile oysters. We are grateful to members of the "Lycée Maritime et Aquacole" de Cherbourg (ferme d'application de Saint-Vaast-La-Hougue) and the "Centre de Recherche en Environnement Côtier" (CREC) in Luc-sur-Mer (especially Jean-Paul Lehodey) for providing technical facilities. We also thank Dr. Aude Jouaux, who quantified the viral loads in oysters at the "Centre de Référence sur l'Huître" (CRH). This work was supported by a grant from both ANR and NSERC Agencies (joined France-Canada project) as a part of the research programme IPOC (Interactions between POllution and Climate changes: Development of improved monitoring strategy, ANR-12-ISV7-0004-01, 2013-2015).

\section{References}

AESN-AQUASCOP, 2008. Guide pratique des Substances Toxiques dans les Eaux Douces et Littorales du bassin Seine-Normandie, AESN. ed., 271 pp.

Almeida, E., Diamantino, T.C., de Sousa, O., 2007. Marine paints: The particular case of antifouling paints. Prog. Org. Coatings 59, 2-20.

Attig, H., Dagnino, A., Negri, A., Jebali, J., Boussetta, H., Viarengo, A., Dondero, F., Banni, M., 2010. Uptake and biochemical responses of mussels Mytilus galloprovincialis exposed to sublethal nickel concentrations. Ecotoxicol. Environ. Saf. 73, 1712-1719. 
Au, D.W.T., 2004. The application of histo-cytopathological biomarkers in marine pollution monitoring: a review. Mar. Pollut. Bull. 48, 817-34.

Auffret, M., 1988. Histopathological changes related to chemical contamination in Mytilus edulis from field and experimental conditions. Mar. Ecol. Prog. Ser. 46, 101-107.

Babo, S., Vasseur, P., 1992. In vitro effects of Thiram on liver antioxidant enzyme activities of rainbow trout (Oncorhynchus mykiss). Aquat. Toxicol. 22, 61-68.

Baudrimont, M., Schäfer, J., Marie, V., Maury-Brachet, R., Bossy, C., Boudou, A., Blanc, G., 2005. Geochemical survey and metal bioaccumulation of three bivalve species (Crassostrea gigas, Cerastoderma edule and Ruditapes philippinarum) in the Nord Médoc salt marshes (Gironde estuary, France). Sci. Total Environ. 337, 265-280.

Bazzi, A.O., 2014. Heavy metals in seawater, sediments and marine organisms in the Gulf of Chabahar, Oman Sea. J. Oceanogr. Mar. Sci. 5, 20-29.

Bebianno, M.J., Pereira, C.G., Rey, F., Cravo, A., Duarte, D., D’Errico, G., Regoli, F., 2015. Intregrated approach to assess ecosystem health in harbor areas. Sci. Total Environ. 514, 92-107.

Binelli, A., Bacchetta, R., Mantecca, P., Ricciardi, F., Provini, A., Vailati, G., 2004. DDT in zebra mussels from Lake Maggiore (N. Italy): level of contamination and endocrine disruptions. Aquat. Toxicol. 69, 175-188.

Bird, P., Comber, S.D.W., Gardner, M.J., Ravenscroft, J.E., 1996. Zinc inputs to coastal waters from sacrificial anodes. Sci. Total Environ. 181, 257-264.

Boutier, B., Chiffoleau, J., Jouanneau, J., Latouche, C., Philipps, I., 1989. Rapports scientifiques et techniques de l'IFREMER ${ }^{\circ} 14$ : LA CONTAMINATION de la GIRONDE par le CADMIUM origine, extension, importance. $106 \mathrm{pp}$.

Bradford, M.M., 1976. A Rapid and Sensitive Method for the Quantitation Microgram Quantities of Protein Utilizing the Principle of Protein-Dye Binding. Anal. Biochem. 72, 248-254.

Buisson, S., Bouchart, V., Guerlet, E., Malas, J.P., Costil, K., 2008. Level of contamination and impact of pesticides in cupped oyster, Crassostrea gigas, reared in a shellfish production area in Normandy (France). J. Environ. Sci. Heal. Part B 43, 655-664.

Cachot, J., Geffard, O., Augagneur, S., Lacroix, S., Le Menach, K., Peluhet, L., Couteau, J., Denier, X., Devier, M.H., Pottier, D., Budzinski, H., 2006. Evidence of genotoxicity related to high PAH content of sediments in the upper part of the Seine estuary (Normandy, France). Aquat. Toxicol. 79, 257-267.

Canesi, L., Viarengo, A., Leonzio, C., Filippelli, M., Gallo, G., 1999. Heavy metals and glutathione metabolism in mussel tissues. Aquat. Toxicol. 46, 67-76.

Caplat, C., Mottin, E., Lebel, J.M., Serpentini, A., Barillier, D., Mahaut, M.L., 2012. Impact of a sacrificial anode as assessed by zinc accumulation in different organs of the oyster Crassostrea gigas: Results from long- and short-term laboratory tests. Arch. Environ. Contam. Toxicol. 62, 638-649.

Chan, K.W., Cheung, R.Y.H., Leung, S.F., Wong, M.H., 1999. Depuration of metals from soft tissues of oysters (Crassostrea gigas) transplanted from a contaminated site to clean sites. Environ. Pollut. 105, 299-310.

Chiffoleau, J.F., Cossa, D., Auger, D., Truquet, I., 1994. Trace metal distribution, partition and 
fluxes in the Seine estuary (France) in low discharge regime. Mar. Chem. 47, 145-158.

Costil, K., Royer, J., Ropert, M., Soletchnik, P., Mathieu, M., 2005. Spatio-temporal variations in biological performances and summer mortality of the Pacific oyster Crassostrea gigas in Normandy (France). Helgol. Mar. Res. 59, 286-300.

Cuevas, N., Zorita, I., Costa, P.M., Franco, J., Larreta, J., 2015. Development of histopathological indices in the digestive gland and gonad of mussels: Integration with contamination levels and effects of confounding factors. Aquat. Toxicol. 162, 152-164.

Enríquez-Díaz, M., Pouvreau, S., Chávez-Villalba, J., Le Pennec, M., 2009. Gametogenesis, reproductive investment, and spawning behavior of the Pacific giant oyster Crassostrea gigas: Evidence of an environment-dependent strategy. Aquac. Int. 17, 491-506.

Farcy, E., Gagné, F., Martel, L., Fortier, M., Trépanier, S., Brousseau, P., Fournier, M., 2011. Short-term physiological effects of a xenobiotic mixture on the freshwater mussel Elliptio complanata exposed to municipal effluents. Environ. Res. 111, 1096-1106.

Freire, C.A., Welker, A.F., Storey, J.M., Storey, K.B., Hermes-Lima, M., 2012. Oxidative stress in estuarine and intertidal environments (temperate and tropical), in: Abele, D., VazquezMedina, J.P., Zenteno-Savin, T. (Eds.), Oxidative Stress in Aquatic Ecosystems. Oxford, 51-57.

Funes, V., Alhama, J., Navas, J.I., López-Barea, J., Peinado, J., 2006. Ecotoxicological effects of metal pollution in two mollusc species from the Spanish South Atlantic littoral. Environ. Pollut. 139, 214-223.

Gabe, M., 1968. Techniques histologiques, Masson. ed. Paris VI. 1113 pp.

Gauthier-Clerc, S., Pellerin, J., Blaise, C., Gagné, F., 2002. Delayed gametogenesis of Mya arenaria in the Saguenay fjord (Canada): A consequence of endocrine disruptors? Comp. Biochem. Physiol. Part c 131, 457-467.

Goldberg, E.D., 1986. The Mussel Watch concept. Environ. Monit. Assess. 7, 91-103.

Gonzalez-Rey, M., Mattos, J.J., Piazza, C.E., Bainy, A.C.D., Bebianno, M.J., 2014. Effects of active pharmaceutical ingredients mixtures in mussel Mytilus galloprovincialis. Aquat. Toxicol. 153, 12-26.

Grangeré, K., Lefebvre, S., Blin, J.-L., 2012. Spatial and temporal dynamics of biotic and abiotic features of temperate coastal ecosystems as revealed by a combination of ecological indicators. Estuar. Coast. Shelf Sci. 108, 109-118.

Guerlet, E., Ledy, K., Giambérini, L., 2006. Field application of a set of cellular biomarkers in the digestive gland of the freshwater snail Radix peregra (Gastropoda, Pulmonata). Aquat. Toxicol. 77, 19-32.

Guerlet, E., Ledy, K., Meyer, A., Giambérini, L., 2007. Towards a validation of a cellular biomarker suite in native and transplanted zebra mussels: a 2-year integrative field study of seasonal and pollution-induced variations. Aquat. Toxicol. 81, 377-388.

Habig, W.H., Pabst, M.J., Jakoby, W.B., 1974. Glutathione S-Transferase: The first enzymatic step in mercapturic acid formation. J. Biol. Chem. 249, 7130-7139.

IFREMER, 2007. Les contaminants chimiques dans les huîtres et les moules du littoral français.http://envlit.ifremer.fr/var/envlit/storage/documents/parammaps/contaminantschimiques/ 
Iummato, M.M., Di Fiori, E., Sabatini, S.E., Cacciatore, L.C., Cochón, A.C., Ríos de Molina, M. del C., Juárez, A.B., 2013. Evaluation of biochemical markers in the golden mussel Limnoperna fortunei exposed to glyphosate acid in outdoor microcosms. Ecotoxicol. Environ. Saf. 95, 123-129.

Lin, Y.-C., Chang-Chien, G.-P., Chiang, P.-C., Chen, W.-H., Lin, Y.-C., 2013. Multivariate analysis of heavy metal contaminations in seawater and sediments from a heavily industrialized harbor in Southern Taiwan. Mar. Pollut. Bull. 76, 266-275.

Lucas, A., Beninger, P.G., 1985. The use of physiological condition indices in marine bivalve aquaculture. Aquaculture 44, 187-200.

Manduzio, H., Rocher, B., Durand, F., Galap, C., Leboulenger, F., 2005. The point about oxidative stress in molluscs. Invertebr. Surviv. J. 2, 91-104.

Marigómez, I., Soto, M., Cajaraville, M.P., Angulo, E., Giamberini, L., 2002. Cellular and subcellular distribution of metals in molluscs. Microsc. Res. Tech. 56, 358-392.

McDowell, J.E., Lancaster, B.A., Leavitt, D.F., Rantamaki, P., Ripley, B., 1999. The effects of lipophilic organic contaminants on reproductive physiology and disease processes in marine bivalve molluscs. Limnol. Oceanogr. 44, 903-909.

Michel, P., Averty, B., 1999. Contamination of French Coastal Waters by Organotin Compounds : 1997 Update. Mar. Pollut. Bull. 38, 268-275.

Moore, M.N., 1988. Cytochemical responses of the lysosomal system and NADPHferrihemoprotein reductase in molluscan digestive cells to environmental and experimental exposure to xenobiotics. Mar. Ecol. Prog. Ser. 46, 81-89.

Mottier, A., Séguin, A., Devos, A., Pabic, C. Le, Voiseux, C., Lebel, J.M., Serpentini, A., Fievet, B., Costil, K., 2015. Effects of subchronic exposure to glyphosate in juvenile oysters (Crassostrea gigas): From molecular to individual levels. Mar. Pollut. Bull. 95, $665-677$.

Nasci, C., Da Ros, L., Campesan, G., Van Vleet, E.S., Salizzato, M., Sperni, L., Pavoni, B., 1999. Clam Transplantation and Stress-Related Biomarkers as Useful Tools for Assessing Water Quality in Coastal Environments. Mar. Pollut. Bull. 39, 255-260.

Nicholson, S., Lam, P.K.S., 2005. Pollution monitoring in Southeast Asia using biomarkers in the mytilid mussel Perna viridis (Mytilidae: Bivalvia). Environ. Int. 31, 121-132.

O'Connor, T.P., Lauenstein, G.G., 2005. Status and trends of copper concentrations in mussels and oysters in the USA. Mar. Chem. 97, 49-59.

Ochoa, V., Barata, C., Riva, M.C., 2013. Heavy metal content in oysters (Crassostrea gigas) cultured in the Ebro Delta in Catalonia, Spain. Environ. Monit. Assess. 185, 6783-6792.

Ochoa, V., Riva, C., Faria, M., de Alda, M.L., Barceló, D., Fernandez Tejedor, M., Roque, A., Barata, C., 2012. Are pesticide residues associated to rice production affecting oyster production in Delta del Ebro, NE Spain? Sci. Total Environ. 437, 209-18.

Oliver, L.M., Fisher, W.S., Winstead, J.T., Hemmer, B.L., Long, E.R., 2001. Relationships between tissue contaminants and defense-related characteristics of oysters (Crassostrea virginica) from five Florida bays. Aquat. Toxicol. 55, 203-222.

RHLN, 2008. (Réseau Hydrologique Littoral Normand) Fiches de suivi de la qualité trophique des masses d'eau. http://envlit.ifremer.fr/region/basse_normandie/qualite/hydrologie/rhln_dce 
RHLN, 2015. (Réseau Hydrologique Littoral Normand) Année 2013: Rapport Scientifique. 156 pp.

Riedel, G.F., Abbe, G.R., Sanders, J.G., 1998. Temporal and spatial variations of trace metal concentrations in oysters from the Patuxent River, Maryland. Estuaries 21, 423-434.

Risso-de Faverney, C., Guibbolini-sabatier, M.E., Francour, P., 2010. An ecotoxicological approach with transplanted mussels (Mytilus galloprovincialis ) for assessing the impact of tyre reefs immersed along the NW Mediterranean Sea. Mar. Environ. Res. 70, 87-94.

Royer, J., Seguineau, C., Park, K.-I., Pouvreau, S., Choi, K.-S., Costil, K., 2008. Gametogenetic cycle and reproductive effort assessed by two methods in 3 age classes of Pacific oysters, Crassostrea gigas, reared in Normandy. Aquaculture 277, 313-320.

Sabatini, S.E., Rocchetta, I., Nahabedian, D.E., Luquet, C.M., Eppis, M.R., Bianchi, L., Ríos de Molina, M. del C., 2011. Oxidative stress and histological alterations produced by dietary copper in the fresh water bivalve Diplodon chilensis. Comp. Biochem. Physiol. Part C 154, 391-398.

Samain, J.-F., McCombie, H., 2007. Summer mortality of Pacific oyster Crassostrea gigas: The Morest project, Quae. ed. Versailles. 400 pp.

Shahidul Islam, M., Tanaka, M., 2004. Impacts of pollution on coastal and marine ecosystems including coastal and marine fisheries and approach for management: a review and synthesis. Mar. Pollut. Bull. 48, 624-49.

Shulkin, V.M., Presley, B.J., Kavun, V.I., 2003. Metal concentrations in mussel Crenomytilus grayanus and oyster Crassostrea gigas in relation to contamination of ambient sediments. Environ. Int. 29, 493-502.

Siah, A., Pellerin, J., Amiard, J.-C., Pelletier, E., Viglino, L., 2003. Delayed gametogenesis and progesterone levels in soft-shell clams (Mya arenaria) in relation to in situ contamination to organotins and heavy metals in the St. Lawrence River (Canada). Comp. Biochem. Physiol. Part C 135, 145-156.

Sokolova, I.M., 2013. Energy-limited tolerance to stress as a conceptual framework to integrate the effects of multiple stressors. Integr. Comp. Biol. 53, 597-608.

Sokolova, I.M., Sukhotin, A.A., Lannig, G., 2012. Stress effects on metabolism and energy budgets in mollusks, in: Abele, D., Vazquez-Medina, J.P., Zenteno-Savin, T. (Eds.), Oxidative Stress in Aquatic Ecosystems. Oxford, 263-280.

Sun, J., Wang, M.-H., Ho, Y.-S., 2012. A historical review and bibliometric analysis of research on estuary pollution. Mar. Pollut. Bull. 64, 13-21.

Turner, A., 2010. Marine pollution from antifouling paint particles. Mar. Pollut. Bull. 60, 159171.

Valdez Domingos, F.X., Azevedo, M., Silva, M.D., Randi, M.A.F., Freire, C.A., Silva de Assis, H.C., Oliveira Ribeiro, C.A., 2007. Multibiomarker assessment of three Brazilian estuaries using oysters as bioindicators. Environ. Res. 105, 350-63.

Vázquez, G.F., Sanchez, G.M., Virender, K.S., 1993. Trace metals in the oyster Crasostrea virginica of the Terminos Lagoon, Campeche, Mexico. Mar. Pollut. Bull. 26, 398-399.

Viarengo, A., Lowe, D., Bolognesi, C., Fabbri, E., Koehler, A., 2007. The use of biomarkers in biomonitoring: a 2-tier approach assessing the level of pollutant-induced stress syndrome in sentinel organisms. Comp. Biochem. Physiol. Part C 146, 281-300. 
Vidal-Liñán, L., Bellas, J., Etxebarria, N., Nieto, O., Beiras, R., 2014. Glutathione Stransferase, glutathione peroxidase and acetylcholinesterase activities in mussels transplanted to harbour areas. Sci. Total Environ. 470-471, 107-16.

Zorita, I., Ortiz-Zarragoitia, M., Soto, M., Cajaraville, M.P., 2006. Biomarkers in mussels from a copper site gradient (Visnes, Norway): An integrated biochemical, histochemical and histological study. Aquat. Toxicol. 78 Suppl 1, 109-116. 
Table 1: Concentrations $\left(\mu \mathrm{g} . \mathrm{L}^{-1}\right)$ of inorganic and organic compounds in seawater from the two shellfish-producing sites (SV and BDV) from the ROCCH database (March 2012 - March 2013) (IFREMER, unpublished data). For each compound, the annual average values are written in bold, and the maximum values are shown in italics and brackets. For each compound, the data were compared to existing norms and regulations: NOEC/EC10 (no observed effect concentration/effective concentration 10) (INERIS, 2014), PNEC (predicted no effect concentration) (AESN-AQUASCOP, 2008) and AA-EQSs (annual average-environmental quality standards) (European Parliament and Council, 2013). The number of norm and regulation exceedances is written in bold and brackets for annual average values and in italics and brackets for maximum values. If a site showed more norm and regulation exceedances, the cell background was coloured in light grey.

\begin{tabular}{|c|c|c|c|c|c|c|c|}
\hline & Water & $\begin{array}{c}\mathbf{Z n} \\
(\mu \mathrm{g} / \mathrm{L}) \\
\end{array}$ & $\begin{array}{c}\mathbf{N i} \\
(\mu \mathrm{g} / \mathrm{L}) \\
\end{array}$ & $\begin{array}{c}\mathbf{P b} \\
(\mu \mathrm{g} / \mathrm{L}) \\
\end{array}$ & $\begin{array}{c}\mathbf{C u} \\
(\mu \mathrm{g} / \mathrm{L}) \\
\end{array}$ & $\begin{array}{c}\text { Octylphenol } \\
(\mu \mathrm{g} / \mathrm{L})\end{array}$ & $\begin{array}{c}\text { Nonylphenol } \\
(\mu \mathrm{g} / \mathrm{L})\end{array}$ \\
\hline \multirow[b]{2}{*}{ SV } & $\begin{array}{c}\text { ROCCH (2012-2013) } \\
\text { average } \\
\text { (maximum) }\end{array}$ & $\begin{array}{c}\mathbf{1 . 1 6} \\
(6.67)\end{array}$ & $\begin{array}{c}\mathbf{1 . 2 5} \\
(9.70)\end{array}$ & $\begin{array}{c}\mathbf{0 . 5 9} \\
(1.67)\end{array}$ & $\begin{array}{c}\mathbf{0 . 5 7} \\
(1.40)\end{array}$ & $\begin{array}{c}\mathbf{0 . 1 0} \\
(0.10)\end{array}$ & $\begin{array}{c}\mathbf{0 . 1 9} \\
(1.30)\end{array}$ \\
\hline & $\begin{array}{c}\text { Exceeding norms and } \\
\text { regulations } \\
\text { average } \\
\text { (maximum) }\end{array}$ & $\begin{array}{l}(\mathbf{0} / \mathbf{1}) \\
(0 / 1)\end{array}$ & $\begin{array}{l}(\mathbf{0} / \mathbf{2}) \\
(2 / 2)\end{array}$ & $\begin{array}{c}(\mathbf{0 / 3}) \\
A A-E Q S(1 / 3)\end{array}$ & $\begin{array}{c}\text { NOEC/EC10 } \\
(\mathbf{1 / 2}) \\
N O E C / E C 10, \\
P N E C(2 / 2) \\
\end{array}$ & $\begin{array}{c}\text { AA-EQS, } \\
\text { PNEC (2/2) } \\
A A-E Q S, \\
P N E C(2 / 2) \\
\end{array}$ & $\begin{array}{c}(\mathbf{0} / \mathbf{3}) \\
A A-E Q S \\
P N E C(2 / 3)\end{array}$ \\
\hline \multirow[b]{2}{*}{ BDV } & $\begin{array}{c}\text { ROCCH (2012-2013) } \\
\text { average } \\
\text { (maximum) }\end{array}$ & $\begin{array}{c}\mathbf{1 . 2 1} \\
(7.56)\end{array}$ & $\begin{array}{c}\mathbf{1 . 3 4} \\
(11.10)\end{array}$ & $\begin{array}{c}\mathbf{0 . 5 6} \\
(1.33)\end{array}$ & $\begin{array}{c}\mathbf{0 . 5 6} \\
(1.30)\end{array}$ & $\begin{array}{c}\mathbf{0 . 1 2} \\
(0.20)\end{array}$ & $\begin{array}{c}\mathbf{0 . 3 0} \\
(1.29)\end{array}$ \\
\hline & $\begin{array}{c}\text { Exceeding norms and } \\
\text { regulations } \\
\text { average } \\
\text { (maximum) }\end{array}$ & $\begin{array}{l}(\mathbf{0} / \mathbf{1}) \\
(0 / 1)\end{array}$ & $\begin{array}{l}(\mathbf{0} / 2) \\
(2 / 2)\end{array}$ & $\begin{array}{c}(\mathbf{0 / 3}) \\
A A-\operatorname{EQS}(1 / 3)\end{array}$ & $\begin{array}{c}\text { NOEC/EC10 } \\
\mathbf{( 1 / 2 )} \\
N O E C / E C 10, \\
P N E C(2 / 2)\end{array}$ & $\begin{array}{c}\text { AA-EQS, } \\
\text { PNEC (2/2) } \\
A A-E Q S, \\
P N E C(2 / 2)\end{array}$ & $\begin{array}{c}\text { AA-EQS (1/3) } \\
A A-E Q S \\
P N E C(2 / 3)\end{array}$ \\
\hline
\end{tabular}


Table 2: Concentrations of inorganic $\left(\mathrm{mg} \cdot \mathrm{kg}^{-1} \mathrm{dw}\right)$ and organic $\left(\mu \mathrm{g} \cdot \mathrm{kg}^{-1} \mathrm{dw}\right)$ compounds in sediments sampled at the two sites (SV and BDV) from the ROCCH database (June 2013) (IFREMER, unpublished data). The regional geochemical background levels (AESNAQUASCOP, 2008) are indicated, and data for each compound were compared to existing norms and regulations: PNEC (predicted no effect concentration) (AESN-AQUASCOP, 2008), BAC (background assessment concentration) (OSPAR Commission, 2014), median (regional median) (IFREMER, unpublished data) and ERL/EAC (effects range-low/environmental assessment criterion) (OSPAR Commission, 2014). The number of norm and regulation exceedances is written in brackets. If a site showed more norm and regulation exceedances, the cell background was coloured in light grey.

\begin{tabular}{ccccccccc}
\hline Sediment & Cd & Zn & Hg & Ni & Pb & Cu & CB153 & Fluoranthene
\end{tabular}

Geochemical background level (AQUASCOP-AESN,

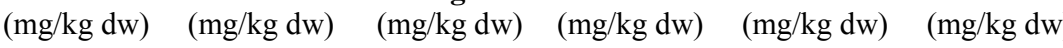
$(\mu \mathrm{g} / \mathrm{kg} \mathrm{dw})$ ( $\mu \mathrm{g} / \mathrm{kg} \mathrm{dw})$

\begin{tabular}{|c|c|c|c|c|c|c|c|c|c|}
\hline & $\begin{array}{c}\text { background level } \\
\text { (AQUASCOP-AESN, } \\
\text { 2008) } \\
\end{array}$ & 0.22 & 60.00 & $\mathbf{0 . 0 3}$ & 16.00 & 20.00 & 15.00 & $x$ & $\times$ \\
\hline \multirow{2}{*}{ SV } & ROCCH (2013) & 0.28 & 95.20 & 0.08 & 24.50 & 40.90 & 15.60 & 1.15 & 48.61 \\
\hline & $\begin{array}{l}\text { Exceeding norms and } \\
\text { regulations }\end{array}$ & $(0 / 4)$ & $(0 / 3)$ & $\mathrm{BAC}(1 / 4)$ & PNEC (1/2) & $\begin{array}{c}\text { PNEC, BAC } \\
(2 / 4)\end{array}$ & $\operatorname{PNEC}(1 / 2)$ & $\mathrm{BAC}(1 / 2)$ & $\begin{array}{c}\text { PNEC, BAC } \\
(2 / 4)\end{array}$ \\
\hline \multirow[b]{2}{*}{ BDV } & ROCCH (2013) & 0.74 & 96.5 & 0.08 & 30.70 & 37.50 & 17.00 & 1.00 & 61.88 \\
\hline & $\begin{array}{l}\text { Exceeding norms and } \\
\text { regulations }\end{array}$ & $\begin{array}{l}\mathrm{BAC}, \\
\text { median } \\
(2 / 4)\end{array}$ & $(0 / 3)$ & $\mathrm{BAC}(1 / 4)$ & $\begin{array}{l}\text { PNEC, } \\
\text { median } \\
(2 / 2)\end{array}$ & PNEC (1/4) & $\begin{array}{c}\text { PNEC, } \\
\text { median } \\
(2 / 2)\end{array}$ & $\operatorname{BAC}(1 / 2)$ & $\begin{array}{c}\text { PNEC, BAC } \\
(2 / 4)\end{array}$ \\
\hline
\end{tabular}


Table 3: Concentrations of inorganic $\left(\mathrm{mg} \cdot \mathrm{kg}^{-1} \mathrm{dw}\right)$ and organic $\left(\mu \mathrm{g} \cdot \mathrm{kg}^{-1} \mathrm{dw}\right)$ compounds in biota (mussels) sampled at the two sites (SV and BDV) from the ROCCH database (November 2013) (IFREMER, unpublished data). For each compound, data were compared to existing norms and regulations: BAC (background assessment concentration) (OSPAR Commission, 2014), median (national median) (IFREMER, unpublished data) and EAC/EC (environmental assessment criterion/European commission food standard) (OSPAR Commission, 2014). The number of norm and regulation exceedances is written in brackets. If a site showed more norm and regulation exceedances, the cell background was coloured in light grey.

\begin{tabular}{|c|c|c|c|c|c|c|c|c|c|}
\hline & Biota (mussels) & $\begin{array}{c}\mathbf{H g} \\
(\mathrm{mg} / \mathrm{kg} \mathrm{dw})\end{array}$ & $\begin{array}{c}\text { Cd } \\
(\mathrm{mg} / \mathrm{kg} \mathrm{dw})\end{array}$ & $\begin{array}{c}\mathbf{C u} \\
(\mathrm{mg} / \mathrm{kg} \mathrm{dw})\end{array}$ & $\begin{array}{c}\mathbf{Z n} \\
(\mathrm{mg} / \mathrm{kg} \mathrm{dw})\end{array}$ & $\begin{array}{c}\mathbf{N i} \\
(\mathrm{mg} / \mathrm{kg} \mathrm{dw})\end{array}$ & $\begin{array}{c}\mathbf{P b} \\
(\mathrm{mg} / \mathrm{kg} \mathrm{dw})\end{array}$ & $\begin{array}{c}\mathbf{A g} \\
(\mathrm{mg} / \mathrm{kg} \mathrm{dw})\end{array}$ & $\begin{array}{c}\text { CB153 } \\
(\mu \mathrm{g} / \mathrm{kg} \mathrm{dw})\end{array}$ \\
\hline \multirow{2}{*}{ SV } & ROCCH (2013) & 0.17 & 0.56 & 6.40 & 67.00 & 4.20 & 1.00 & 0.37 & 10.22 \\
\hline & $\begin{array}{c}\text { Exceeding norms and } \\
\text { regulations }\end{array}$ & $\begin{array}{c}\text { BAC, median } \\
(2 / 3)\end{array}$ & $(0 / 3)$ & $\operatorname{BAC}(1 / 1)$ & $\operatorname{BAC}(1 / 2)$ & median $(1 / 1)$ & $(0 / 0)$ & median $(1 / 1)$ & $\operatorname{BAC}(1 / 3)$ \\
\hline \multirow{2}{*}{ BDV } & ROCCH (2013) & 0.07 & 0.31 & 5.8 & 40.00 & 0.66 & 0.50 & 0.11 & 10.86 \\
\hline & $\begin{array}{l}\text { Exceeding norms and } \\
\text { regulations }\end{array}$ & $(0 / 3)$ & $(0 / 3)$ & $(0 / 1)$ & $(0 / 2)$ & $(0 / 1)$ & $(0 / 0)$ & median $(1 / 1)$ & $\operatorname{BAC}(1 / 3)$ \\
\hline
\end{tabular}


Table 4: Summary of the experimental design according to sampling dates in 2013, endpoints, metal analyses, and sample size. * Oysters sampled for histopathology and biochemical endpoints were also used to determine the AFNOR condition index.

\begin{tabular}{|c|c|c|c|c|c|c|c|c|c|c|}
\hline & & T0 & $\mathrm{T} 24 \mathrm{~h}$ & $\mathrm{~T} 48 \mathrm{~h}$ & $\mathrm{~T} 15 \mathrm{~d}$ & $\mathrm{~T} 1.5 \mathrm{~m}$ & $\mathrm{~T} 2 \mathrm{~m}$ & $\mathrm{~T} 3 \mathrm{~m}$ & $\mathrm{~T} 5 \mathrm{~m}$ \\
\hline & & & $\begin{array}{l}09 / 02- \\
13 / 02 \\
\end{array}$ & $\begin{array}{l}10 / 02- \\
12 / 02 \\
\end{array}$ & $\begin{array}{l}11 / 02- \\
13 / 02 \\
\end{array}$ & $\begin{array}{l}26 / 02- \\
28 / 02 \\
\end{array}$ & $\begin{array}{l}26 / 03- \\
28 / 03 \\
\end{array}$ & $\begin{array}{l}09 / 04- \\
11 / 04 \\
\end{array}$ & $\begin{array}{l}07 / 05- \\
10 / 05 \\
\end{array}$ & $\begin{array}{l}10 / 07- \\
12 / 07 \\
\end{array}$ \\
\hline \multirow{2}{*}{$\begin{array}{r}\text { Metal } \\
\text { analyses } \\
\end{array}$} & Water & 1 liter & & & & & $\mathrm{X}$ & & $\mathrm{X}$ & \\
\hline & Oysters & $\mathrm{n}=30$ & & & & $\mathrm{X}$ & & & $X$ & $\mathrm{X}$ \\
\hline \multirow{3}{*}{$\begin{array}{l}\text { Individual } \\
\text { endpoints }\end{array}$} & Mortality & $n=50$ & & & & $\mathrm{X}$ & $X$ & $X$ & $\mathrm{X}$ & \\
\hline & Growth & & & & & X & & & $\mathrm{X}$ & \\
\hline & $\begin{array}{c}\text { Condition } \\
\text { index }\end{array}$ & $\mathrm{n}=18^{*}$ & $\mathrm{X}$ & & & & $\mathrm{X}$ & $\mathrm{X}$ & $\mathrm{X}$ & \\
\hline \multirow[t]{2}{*}{$\begin{array}{l}\text { Histological } \\
\text { endpoints }\end{array}$} & $\begin{array}{c}\text { Reproduction } \\
\text { and } \\
\text { histopathology }\end{array}$ & $\mathrm{n}=10-30$ & $\mathrm{X}$ & & $X$ & & $\mathrm{X}$ & $\mathrm{X}$ & $X$ & $X$ \\
\hline & UNL & $\mathrm{n}=10$ & $\mathrm{X}$ & $\mathrm{X}$ & $\mathrm{X}$ & & $\mathrm{X}$ & $\mathrm{X}$ & $\mathrm{X}$ & \\
\hline \multirow{3}{*}{$\begin{array}{l}\text { Biochemical } \\
\text { endpoints }\end{array}$} & Catalase & & $\mathrm{X}$ & $X$ & $\mathrm{X}$ & & $\mathrm{X}$ & $\mathrm{X}$ & $\mathrm{X}$ & \\
\hline & GST & $\mathrm{n}=8$ & $\mathrm{X}$ & $X$ & $X$ & & $X$ & $X$ & $\mathrm{X}$ & \\
\hline & MDA & & $\mathrm{X}$ & $\mathrm{X}$ & $\mathrm{X}$ & & $\mathrm{X}$ & $\mathrm{X}$ & $\mathrm{X}$ & \\
\hline
\end{tabular}




\section{Captions for figures}

Fig. 1: Location of the three sampling sites in the Normandy coast (northwest France): SaintVaast-la-Hougue (SV), Baie des Veys (BDV) and Courseulles-sur-Mer (CsM).

Fig. 2: Trace metal concentrations (mean \pm SEM, in milligrams per kilogram of dry weight) measured in pools of oysters $(N=3)$ placed at SV (Saint-Vaast-la-Hougue), BDV (Baie des Veys) and CsM (Courseulles-sur-Mer) at three sampling dates (T15d: February 2013; T3m: May 2013 and T5m: July 2013). If norm and regulation thresholds are available, red dotted lines indicate the BAC (background assessment concentration) (OSPAR Commission, 2014), black dotted lines indicate the French median (IFREMER, unpublished data), and black solid lines indicate the EAC/EC (environmental assessment criterion/European commission food standard) (OSPAR Commission, 2014).

Fig. 3: Growth in length and weight (mean $\pm \mathrm{SEM} ; N=50$ ) of sub-batches of oysters sampled at two dates (T15d: February 2013 and T3m: May 2013) and at the three studied sites (SV, BDV and CsM). The significance of differences between sites and dates were tested through ANOVAs followed by SNK post-hoc tests. Groups that do not share a common letter are significantly different.

Fig. 4: AFNOR condition index (mean $\pm \mathrm{SEM} ; N=20$, except at $\mathrm{T} 0: N=30$ ) calculated for oysters placed at SV, BDV and CsM and sampled at three sampling dates (T1.5m: March 2013; T3m: May 2013 and T5m: July 2013). At each date, inter-site comparisons were analysed by ANOVAs followed by SNK post-hoc tests. Sites that do not share a common letter are significantly different. 
Fig. 5: Proportion of the five oyster gametogenesis stages and sub-stages [I, IIe (e = early), IIwa $($ wa $=$ well advanced), IIIA and IIIB (for stage description, see text)] observed at five sampling dates (T0: February 2013; T1.5m: March 2013; T2m: April 2013; T3m: May 2013 and T5m: July 2013) and at the three sites (SV, BDV and CsM). The oyster gender (female, male and hermaphrodite) was determined only when the gametogenesis cycle was sufficiently advanced (stage IIe; T3m and T5m). To test the inter-site differences, the gametogenesis sub-stages were pooled, and Fisher's tests were applied. Sites that do not share a common letter are significantly different.

Fig. 6: Mean severity index (mean $\pm \mathrm{SEM}, N=10$ at $\mathrm{T} 1.5 \mathrm{~m}$ and $\mathrm{T} 3 \mathrm{~m} ; N=30$ at $\mathrm{T} 0$ and $\mathrm{T} 5 \mathrm{~m}$ ) of (a) destructurations of the connective tissue and (b) hemocytic infiltrations in connective tissue at four sampling dates (T0: February 2013; T1.5m: March 2013; T2m: April 2013 and T3m: May 2013) and at the three sites (SV, BDV and CsM). At each date, inter-site differences were analysed through non parametric K-W tests followed by Dunn tests. Sites that do not share a common letter are significantly different.

Fig. 7: Surface density $\left(\mathrm{S}_{\mathrm{v}}\right)$ of unsaturated neutral lipids (UNLs) (mean $\pm \mathrm{SEM} ; N=6$ and 8 fields per histochemistry slide) at three sampling dates (T1.5m: March 2013; T2m: April 2013 and T3m: May 2013) and at the three sites (SV, BDV and CsM). At each date, inter-site differences were analysed by ANOVAs followed by SNK post-hoc tests. Sites that do not share a common letter are significantly different.

Fig. 8: Oxidative stress parameters (mean $\pm \mathrm{SEM} ; N=8$ ) at three sampling dates (T1.5m: March 2013; T2m: April 2013 and T3m: May 2013) and at the three sites (SV, BDV and CsM): 
glutathione-S-transferase (GSTs) activities in nmol. $\mathrm{min}^{-1} \cdot \mathrm{mg}^{-1}$ proteins (a); catalase (CAT) activities in U CAT.mg ${ }^{-1}$ proteins (b) and malondialdehyde (MDA) content in nmol MDA.mg${ }^{1}$ proteins $(\mathrm{c})$. At each date, inter-site differences were analysed through ANOVAs followed by SNK post-hoc tests. Sites that do not share a common letter are significantly different. 


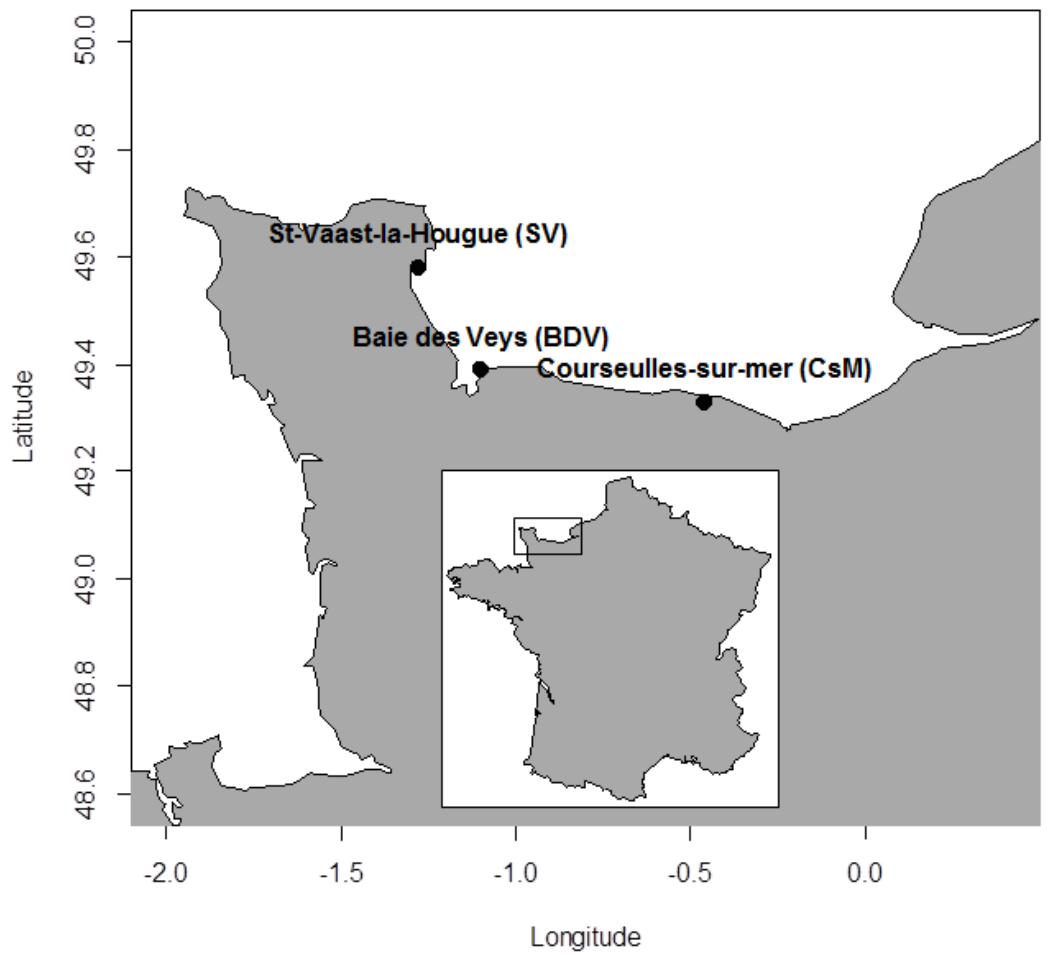

Figure 1 
Cd
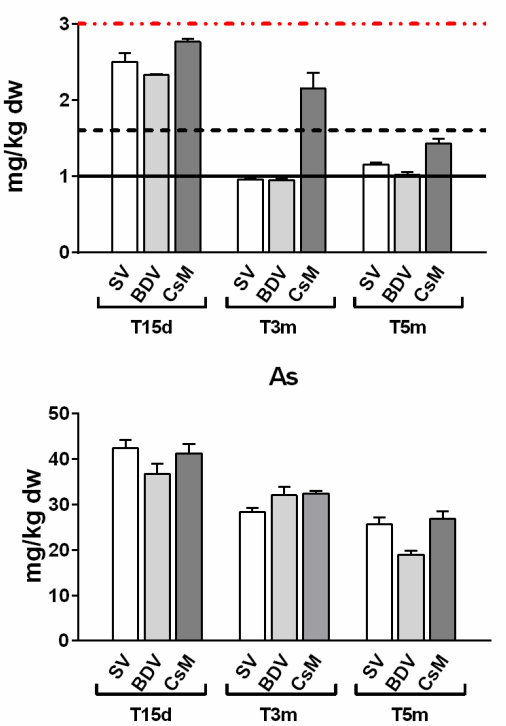

$\mathrm{Pb}$

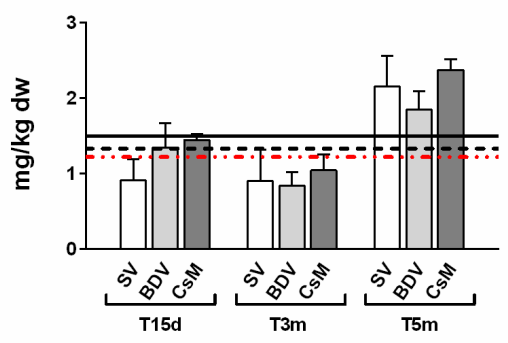

Zn

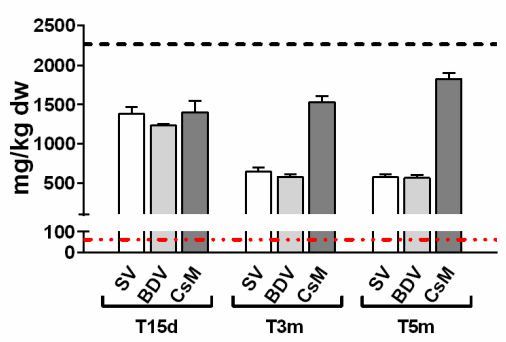

Cu

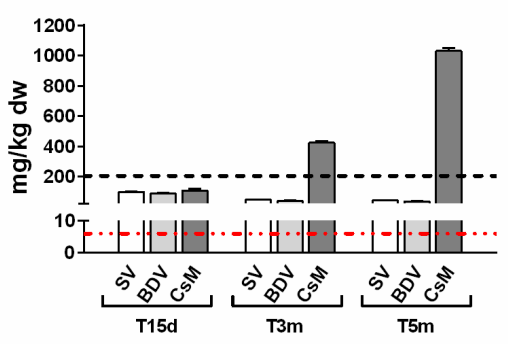

- - - . BAC

EAC/EC median

Figure 2 

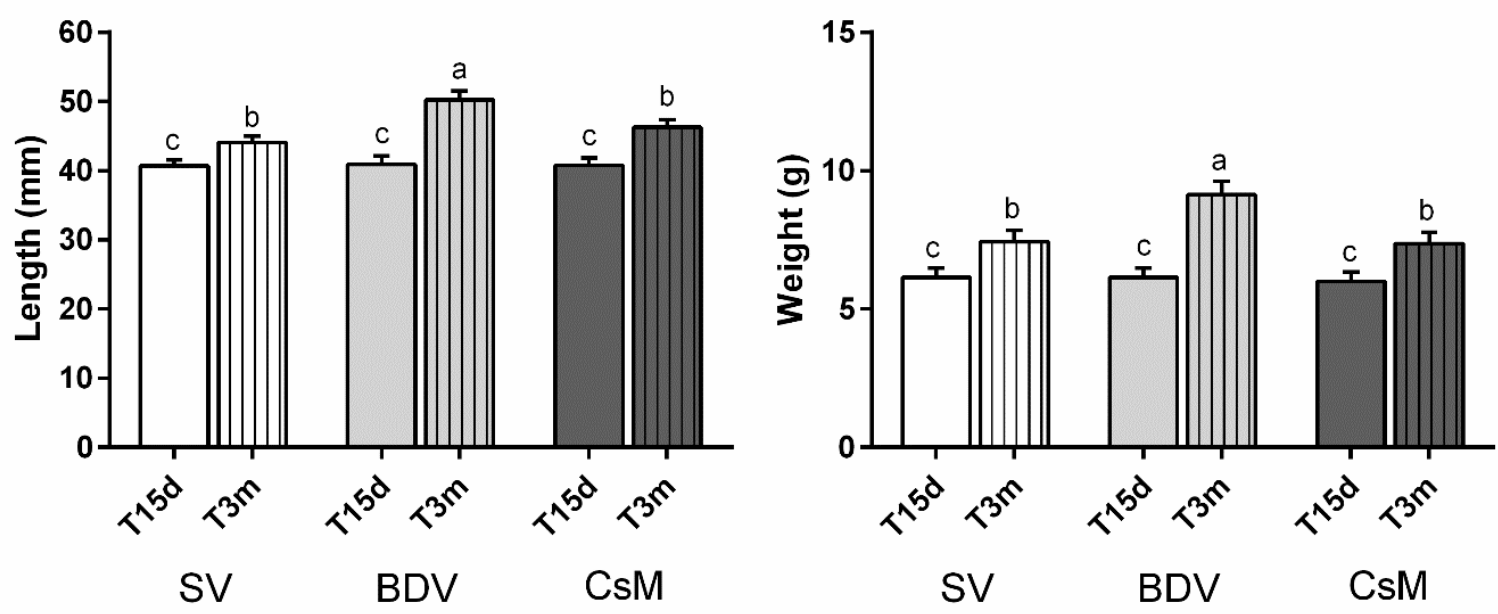

Figure 3 

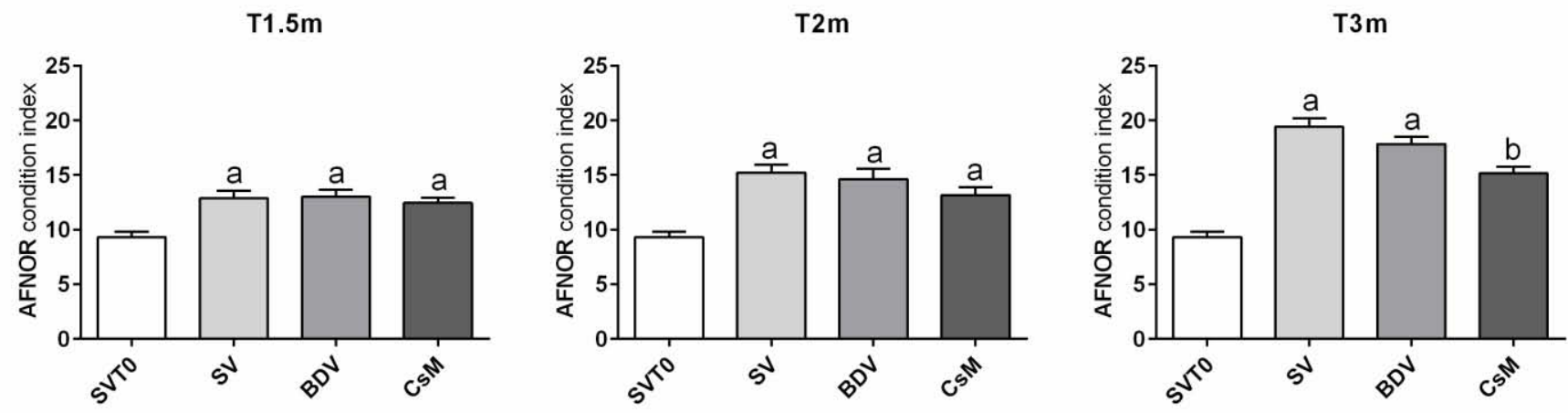

Figure 4 


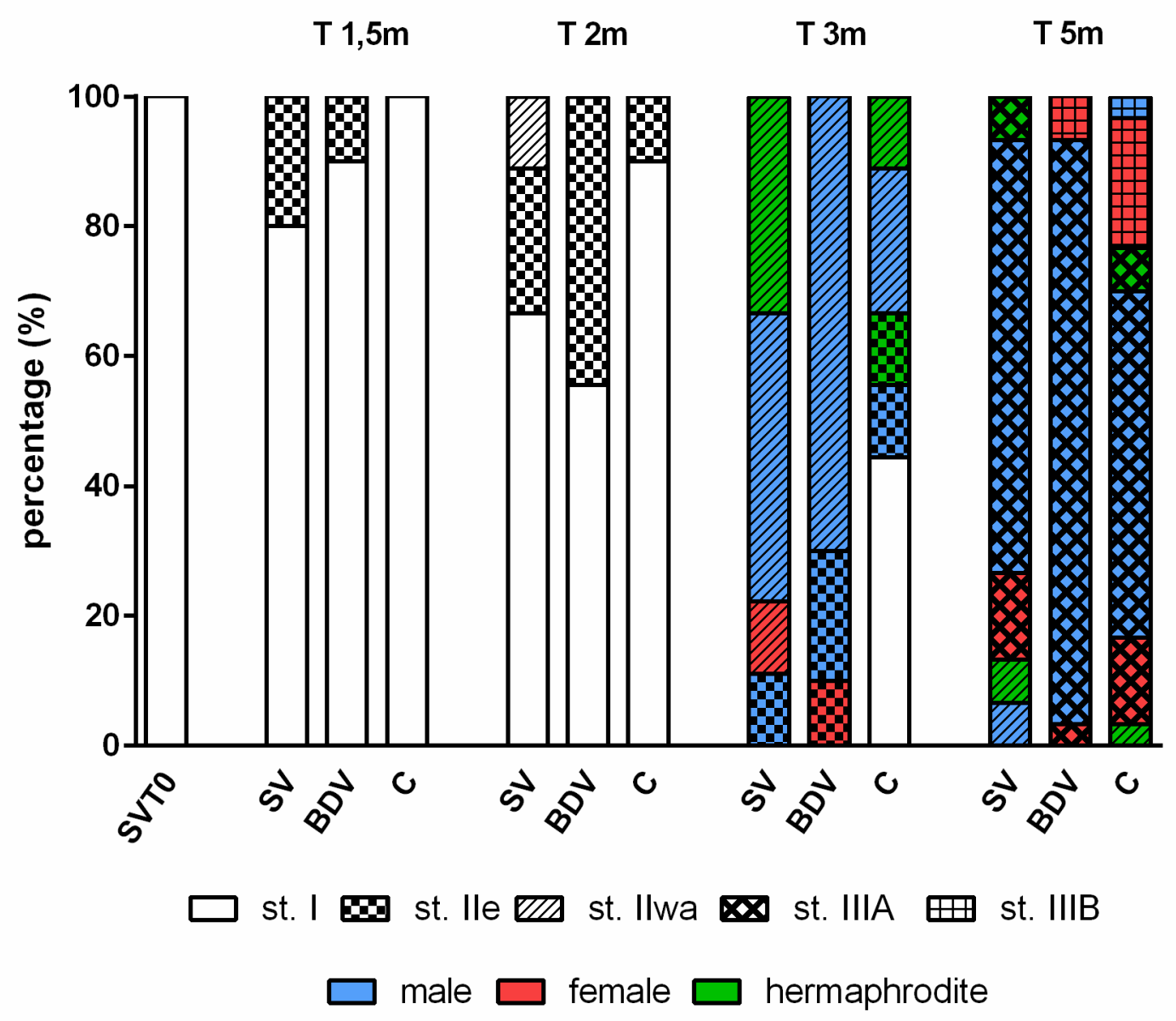

Figure 5 

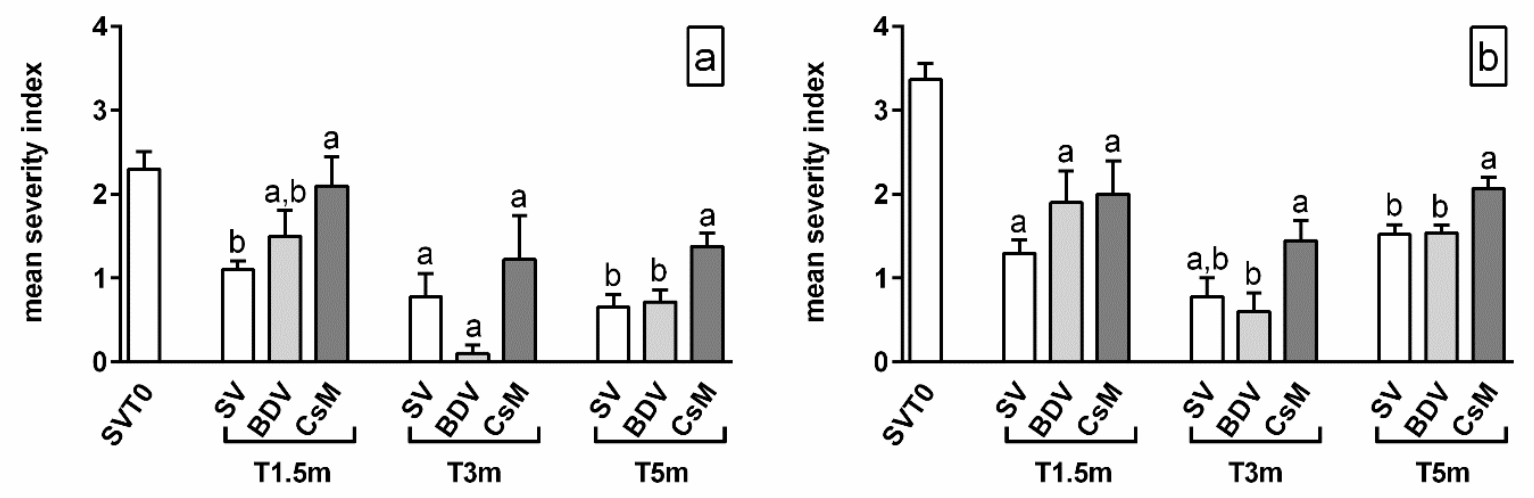

Figure 6 

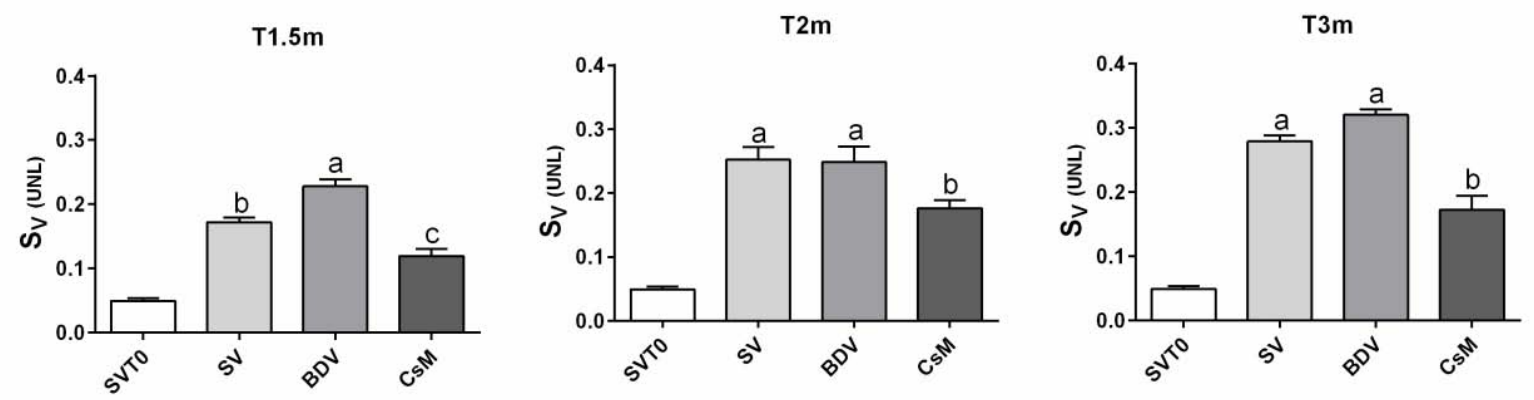

Figure 7 
T1.5m
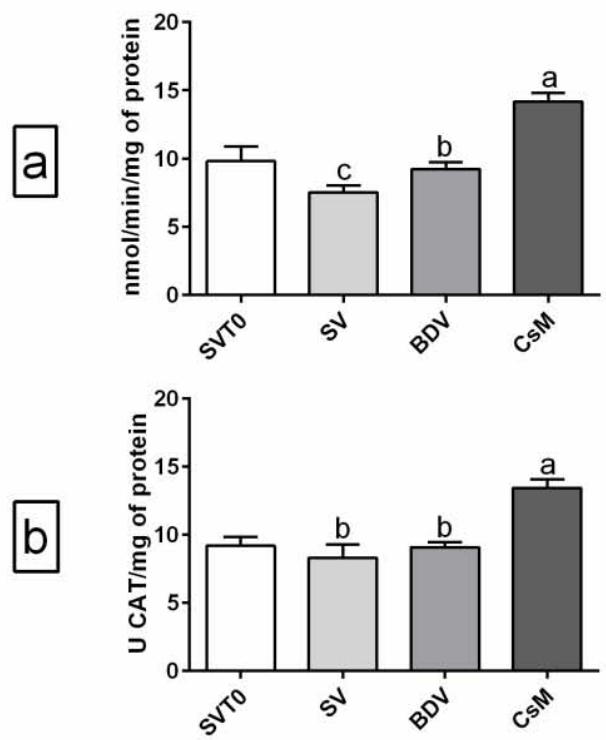

c

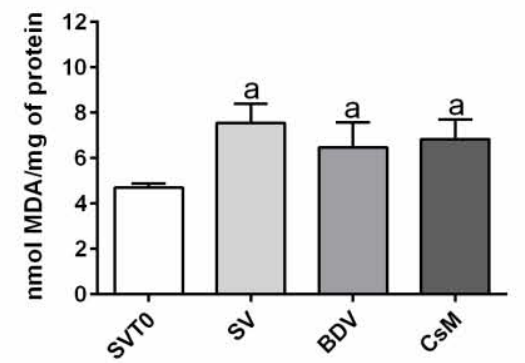

T2m
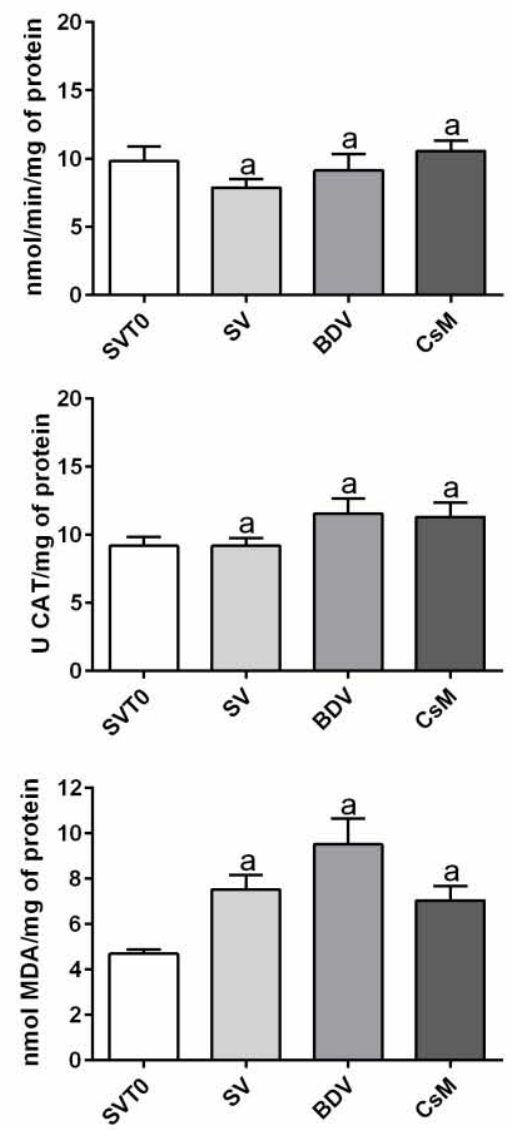

T3m
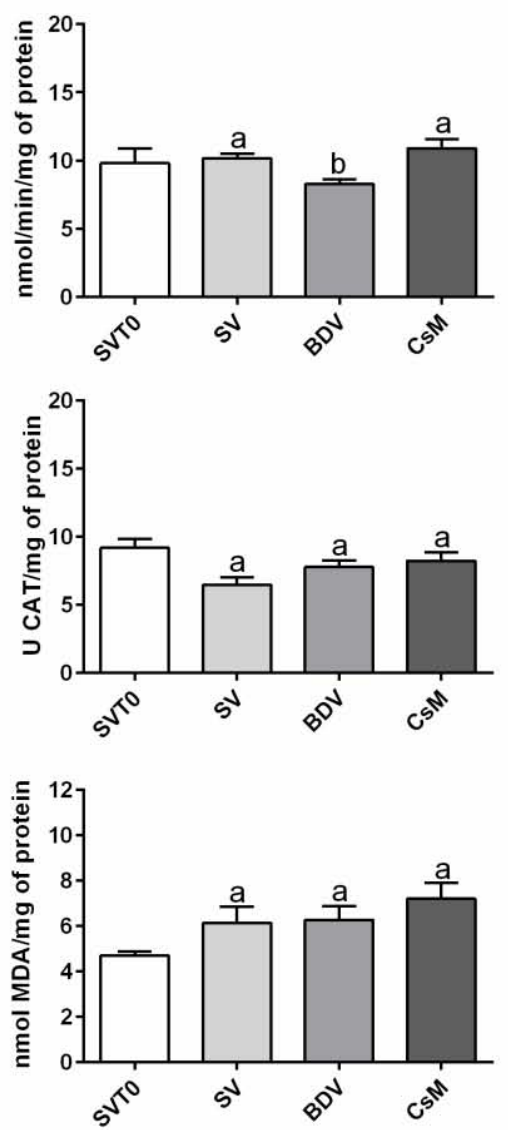

Figure 8 
Appendix A. Description of norms and regulations relative to contamination.

\begin{tabular}{|c|c|c|}
\hline Norms and regulations & Description & Source \\
\hline BAC & $\begin{array}{l}\text { The background assessment concentration (BAC) is the threshold below which a concentration is considered to } \\
\text { be near the background level. }\end{array}$ & OSPAR Commission, 2014 \\
\hline EAC & $\begin{array}{l}\text { The environmental assessment criterion (EAC) is the value below which a concentration should not induce any } \\
\text { chronic effects in marine species. }\end{array}$ & OSPAR Commission, 2014 \\
\hline ERL & $\begin{array}{l}\text { The effects range-low (ERL) is the value below which a concentration rarely causes adverse effects in marine } \\
\text { organisms. ERLs are used as an alternative solution when recommended EACs are not available. }\end{array}$ & OSPAR Commission, 2014 \\
\hline EC & $\begin{array}{l}\text { The European commission food standard (EC) is used in the absence of any satisfactory criteria for assessing the } \\
\text { ecological significance of chemical concentrations in biota. ECs correspond to the maximum acceptable } \\
\text { concentrations in food for the protection of public health. }\end{array}$ & OSPAR Commission, 2014 \\
\hline AA-EQS & $\begin{array}{l}\text { The Annual Average-Environmental Quality Standards (AA-EQSs) constitute the annual average concentration of } \\
\text { a given pollutant or group of pollutants in seawater, which should not be exceeded to protect human health and } \\
\text { the environment. }\end{array}$ & $\begin{array}{l}\text { European Parliament and } \\
\text { Council, } 2013\end{array}$ \\
\hline PNEC & $\begin{array}{l}\text { The Predicted No Effect Concentration (PNEC) is the concentration below which exposure to a compound is not } \\
\text { expected to cause adverse effects to species in the environment. }\end{array}$ & AESN-AQUASCOP, 2008 \\
\hline NOEC & $\begin{array}{l}\text { The No Observed Effect Concentration (NOEC) is the highest concentration of a tested compound that has no } \\
\text { effect on the organisms exposed to it or more formally that does not lead to a statistically significant deviation } \\
\text { from a control. }\end{array}$ & INERIS, 2014 \\
\hline $\mathrm{EC}_{10}$ & $\begin{array}{l}\text { The Effective Concentration } 10\left(\mathrm{EC}_{10}\right) \text { represents the concentration of a compound that results in } 10 \% \text { of its } \\
\text { maximal effect. }\end{array}$ & INERIS, 2014 \\
\hline national median & $\begin{array}{l}\text { The national median corresponds to the French median concentration of contaminants in mussels along the } \\
\text { French coasts in the scope of the ROCCH network between } 2009 \text { and } 2013 \text {. This data analysis is only based on } \\
\text { concentrations in mussel flesh because results in oysters at the BDV site are not available. }\end{array}$ & $\begin{array}{l}\text { Unpublished data from } \\
\quad \text { IFREMER }\end{array}$ \\
\hline
\end{tabular}

\section{References}

- AESN-AQUASCOP, 2008. Guide pratique des Substances Toxiques dans les Eaux Douces et Littorales du bassin Seine-Normandie, 271 p., AESN. ed.

- European Parliament and Council, 2013. Directive 2013/39/UE, Official Journal of the European Union, 17 p., http://eurlex.europa.eu/LexUriServ/LexUriServ.do?uri=OJ:L:2013:226:0001:0017:EN:PDF

- INERIS, 2014. Portail Substances Chimiques. http://www.ineris.fr/substances/fr/

- OSPAR Commission, 2014. Levels and trends in marine contaminants and their biological effects - CEMP Assessment report 2013,22 p., http://www.ospar.org/documents?v=7366 